The author(s) shown below used Federal funds provided by the U.S. Department of Justice and prepared the following final report:

Document Title: Sexual Assault in Maryland: The African American Experience

Author(s):

Mark D. Weist ; Jennifer Pollitt-Hill ; Linda Kinney ; Yaphet Bryant ; Laura Anthony ; Jennifer Wilkerson

Document No.: $\quad 217617$

Date Received: March 2007

Award Number: 2003-MU-MU-0001

This report has not been published by the U.S. Department of Justice. To provide better customer service, NCJRS has made this Federallyfunded grant final report available electronically in addition to traditional paper copies.

Opinions or points of view expressed are those of the author(s) and do not necessarily reflect the official position or policies of the U.S. Department of Justice. 
This document is a research report submitted to the U.S. Department of Justice. This report has not been published by the Department. Opinions or points of view expressed are those of the author(s) and do not necessarily reflect the official position or policies of the U.S. Department of Justice.

\section{Sexual Assault in Maryland: The African American Experience Executive Summary}

In the fall of 2003, the University of Maryland School of Medicine, Center for School Mental Health Assistance in collaboration with the Maryland Coalition Against Sexual Assault undertook a research project that sought to examine and better understand the unique experiences of female African American sexual assault survivors in the State of Maryland. This project, funded by the National Institute of Justice, was titled, Sexual Assault in Maryland: The African American Experience, and will be referred to as 'the study' within this summary.

\section{The three main goals of the study were to:}

- Better understand the problem of sexual assault among African American women in Maryland;

- Assess their use of available resources in response to sexual assault; and

- Explore their use of alternative sources of care.

As a result of broadening our understanding with regard to African American survivors it was intended that information gained through the study would be used to improve services for this segment of the population as well as to help fill existing gaps in research. These research findings could then also be used to implement and/or improve policies that would more appropriately address the issue on both state and national levels.

Up to and including this study there has been limited research on the sexual victimization of African American women specific to post assault responses. Likewise, there is minimal research on the consequences and barriers to reporting or help seeking behaviors among different ethnic groups. Given the overwhelming historical context of rape as a method to control and oppress Black women throughout slavery in America, it can be easily anticipated that unique issues will occur when race, gender and sexual violence intersect. These anticipated issues became the key themes to be investigated by the study and ultimately helped frame the hypotheses.

The study began with a thorough literature review of previous studies on the topic, formulation of a multi-disciplinary, African American advisory panel, and hosting of a series of focus groups. Focus groups were conducted with staff from Maryland's rape recovery programs, domestic violence programs, sexual assault forensic exam programs and historically black colleges and universities in our State. The purpose of the focus groups was to gain greater insight into the experience that service providers have in responding to African American survivors including unique needs or barriers to healing. 


\section{Some of the key themes identified as part of the focus groups were as follows:}

\section{Barriers to Reporting}

- Stereotyping and/or victim-blaming response to victims who had been using drugs and/or alcohol;

- Experience of racism by police officers; and

- Reluctance to report sexual crimes of African American males.

Barriers to Accessing Counseling Services

- Difficulty with acceptance of mental health services;

- Belief that mental health issues are a "way of life";

- Belief that African American women can "take care of themselves";

- Belief that "concrete" services (e.g., for housing, employment) are more of a concern than less concrete (e.g., counseling); and

- Belief that in challenging situations (e.g., in public housing) survivors may be too busy taking care basic needs to participate in counseling services.

Recommendations for Improvement in Response Systems

- Enhance access to services (e.g., through transportation, financial assistance);

- Remove stigma from therapy and medication services;

- Enhance relevant educational programs (e.g., on safety issues, acquaintance and statutory rape);

- Enhance resources for public awareness;

- Increase resources for alternative methods of healing (e.g., art, drama, meditation); and

- Better train police officers to competently work with victims.

The main source of data for the study came from face to face interviews with African American and Caucasian sexual assault survivors who were asked about details of the sexual assault, medical care, law enforcement response, prosecution/court process, sexual assault center services, other counseling services, and recommendations for improvement in Maryland's sexual assault response systems. Survivors had to meet the following criterion to be eligible for participation in the study:

- African American or Caucasian female;

- Currently age 18 or over;

- Current resident of Maryland; and

- Experienced sexual assault/abuse at some point in life (including as child).

Participants were recruited through a variety of sources including rape recovery centers, domestic violence centers, sexual assault forensic exam programs, colleges and universities, community-based human service programs, and detention centers. Interviews were conducted with 139 African American survivors and 83 Caucasian survivors for a total of 222 interviews (an additional two women participated but did not 
indicate their racial status). Participants received a stipend of $\$ 10$ for their voluntary participation.

Important to the interview process was ensuring the racial matching of the interviewer to the interviewee for all African American participants to better allow for a free exchange of information. In addition, interviews were conducted as often as possible at local rape recovery centers so that study participants would have immediate access to crisis counseling if needed and would also get the opportunity to learn more about local resources. There were no concerns or complaints expressed from survivors about the content or process of the interviews and in fact a few even found the interviews to be therapeutic. Interviews lasted anywhere from 45 minutes to 2 hours depending on how many response systems the survivor accessed.

The study explored eight specific hypotheses, and while it was expected that there would be substantial differences in victimization and in the manner in which systems responded to African American women compared to Caucasian women there were in fact minimal statistically significant differences found between the two races.

\section{A summary of the research findings by hypothesis follows:}

- African American women will be more likely to experience sexual assault by a stranger

Overall, study findings supported prior research data that indicates most victims of sexual assault know the perpetrator prior to their victimization. In this study, 69\% of study participants knew the perpetrator and only $31 \%$ of respondents categorized the perpetrator as a stranger.

Specific to whether African American women were more likely to be assaulted by a stranger, findings were not supportive with $33 \%$ of African American women reporting a stranger assault compared to $28 \%$ of Caucasian reporting the same. Both groups of women were equally likely to experience a stranger assault.

\section{- Sexual assaults against African American women will be more intense}

Intensity of a sexual assault was measured in terms of sustained injuries to victims and whether weapons were involved in the assault. Data indicated that African American women were not more likely to have sustained physical injuries, nor to have had a weapon used against them. In fact, when looking at the specific injuries women sustained, there were no reports of differences, other than that Caucasian women were more likely to sustain internal injuries from their attack.

- Fewer African American women will report their sexual assault to the police

Overall, there was no difference based on race in the rate of reporting the assault to the police. The large majority of women did not plan to file criminal charges, regardless of race. 
However, there was a statistically significant finding upon the inclusion of an income variable. When this variable was added and reviewed in terms of who reports to police and with what frequency, it was ascertained that African American women with a high level of income were less likely to tell police than Caucasian women with high incomes. With the variable of income added there was partial support for this hypothesis.

- African American women will indicate a number of racial and cultural barriers to reporting sexual assault to the police

While African American women did report a number of barriers to reporting sexual assault to police, there were no clear racial differences in data used to explore this hypothesis.

As discussed previously, only African American women with high income levels were less likely to report their assaults to the police. Their identified barriers to reporting centered on themes of being 'too young' to understand the criminality of their sexual assault and not knowing what to do or where to go for help. Additional barriers included desire to maintain confidentiality, perceived re-victimization, personal blame/guilt and simple fear of the police.

Another dimension of barriers to reporting was satisfaction with police encounters. Many women reported feeling dissatisfied with their interactions with the police, but there were no differences in satisfaction based on the victim's race. There were no significant differences in how African American and Caucasian women rated their satisfaction with the police, with how police handled their case, or with how satisfied they were with their overall interactions with police. Generally, both groups rated their encounters with police with dissatisfaction. For African American women approximately 35\% indicated being 'dissatisfied or very dissatisfied' with their overall interactions with police and $46 \%$ of Caucasian women reported the same.

Study findings supported prior research data that indicate that victims of sexual assault are much more likely to be assaulted by someone of their own race.

\section{- Fewer African American women will report seeking medical and psychological services}

For this hypothesis, medical and psychological services were measured in terms of actual medical treatment sought and received, utilization of sexual assault crisis centers, and receipt of counseling services from other sources.

The findings indicated that there were no significant differences in the rates of medical treatment by African American women compared with Caucasian women. However, when the variable of education was examined, Caucasian women with low levels of education were significantly less likely than African American women with low education to seek medical care. 
In terms of the other measures, African American women were significantly less likely to receive services from a sexual assault crisis center, less likely to receive counseling services from sources other than a sexual assault crisis center, and less likely to obtain services from a therapist or counselor. For African American women who did obtain counseling services outside of a sexual assault crisis center, they were nearly twice as likely as their Caucasian counterparts to have that source be something other than a therapist, hospital or pastor.

- African American will report a number of racial and cultural barriers in seeking and receiving medical and psychological services after a sexual assault

Barriers indicated in this study area largely echo those described in earlier sections. Recurrent themes were lack of knowledge about sexual assault crisis centers (SACC), issues of being 'too young' at the time of victimization, confidentiality issues and a preference for familial support. While barriers were reported to seeking and receiving medical and psychological services following an assault, there were no racial differences in perceptions of these barriers.

In terms of medical treatment, there was one racial difference not related to barriers that the study found. African American women were more likely to be tested for sexually transmitted diseases than Caucasian women with 83\% of African American women being tested for STDs versus $64 \%$ of Caucasian women.

When sexual assault crisis center services were received by African American women after an assault, survivors were generally pleased with those services. 93\% of African American women rated their experiences at SACC's as 'good' or 'very good.' When reporting on counseling received (although less likely to seek these services) 96\% of these same respondents were either 'satisfied' or 'very satisfied.' African American survivors did however report a lower satisfaction with SACC hotline services with slightly more than $15 \%$ stating that they were' very dissatisfied' with hotline services.

It is important to note that both African American and Caucasian women took extended periods of time to access psychological services after an assault with over $55 \%$ of survivors taking more than a year to seek out sexual assault crisis centers and nearly $67 \%$ of survivors taking more than a year to begin counseling services. Regardless of race, the majority of survivors (84\%) reported not knowing about SACCs prior to the assault.

- African American women will receive less medical and psychological care compared with Caucasian women and report more problems receiving this care

$28 \%$ of African American women expressed that race was a factor in the response to their assault versus $13 \%$ of Caucasian women. Interestingly enough, Caucasian women with a higher level of education were much more likely to believe that the race of the perpetrator was a factor in how they were treated. 
In terms of qualitative themes, African American respondents identified racism, stereotypes about poverty, issues of not being perceived as a victim, and involvement with drugs and prostitution as issues that impacted the response to their assault. However, there were no differences based on race in the perpetrator arrest status or the case prosecution status.

When asked to identify the "biggest problem" in their treatment experience, African American women were more likely to report unaddressed childhood abuse, whereas, Caucasian women were significantly more likely to report difficulty in finding mental health services.

- African American women will be more likely to utilize family, friends, and faith communities to deal with the aftermath of their sexual victimization

There was a different pattern of the first person told about the assault for African American women as compared to Caucasian women. African American women were more likely to first tell a relative, medical professional or no one at all, while Caucasian women were more likely to tell a friend first.

African American and Caucasian women were equally unlikely to receive counseling services from their church or pastor. However, African American women were more likely to use religion as a way to cope with the aftermath of sexual assault than Caucasian women who were more likely to use counseling.

Overall, both African American and Caucasian survivors reported counseling services as the most helpful service or experience (38\%) as well as supportive family and friends (17\%). However, Caucasian women were more likely to report that counseling was the most helpful service or experience for them, while African American women were more likely to report that medical personnel were the most helpful service or experience for them.

\section{Conclusions and Next Steps}

Surprisingly, the general overall findings of the study did not amplify any statistically significant differences in the experience of African American and Caucasian women who have experienced sexual assault. The failure to prove the hypotheses may be related to the small sample size of the women interviewed. However, there were important pieces of information documented in this study that both underscore prior research on the experience of sexual assault survivors and suggest further research or indicate future policy development. Salient learning points and suggested next steps are as follows:

- $69 \%$ of study participants knew the perpetrator.

- Survivors took an extended period of time to access psychological services after an assault with nearly $67 \%$ of survivors taking more than a year to begin counseling services. 
- African American survivors were significantly less likely to receive services from a sexual assault crisis center, less likely to receive counseling services from sources other than a sexual assault crisis center, and less likely to obtain services from a therapist or counselor.

- For those African American survivors who did receive sexual assault counseling services, $96 \%$ were either 'satisfied' or 'very satisfied' suggesting that counseling works.

- The need for better marketing of sexual assault crisis center services was indicated. The public must be made aware of the existence of theses centers, where they are and what they do. They must be marketed as part of the community a helpful and beneficial place for relief and recovery. Particular emphasis should be placed on dismantling the stigma of counseling or therapy.

- There is a need for emphasis on breaking the 'culture of silence' regarding rape in African American communities. Information about childhood abuse and how to access tools for recovery should be produced and distributed. Also suggested would be brochures on keeping kids safe and warning signs.

- Victim sensitivity trainings at sexual assault crisis centers and for law enforcement must include cultural competence as a key theme.

- Enhanced skill training should be provided to hotline providers so that African American survivors will be better served.

- There is a significant need to educate the community about 'how they can help' when sexual assaults occur, or when disclosures are made to private individuals. Especially important is their ability to refer an individual to a sexual assault crisis center.

Authors of this executive summary and full report are Mark D. Weist, Jennifer Pollitt Hill, Linda Kinney, Yaphet Bryant, Laura Anthony, and Jennifer Wilkerson. This study was supported by the research grant \#2003-MU-MU-0001 from the National Institute of Justice, U.S. Department of Justice, 2003-2006. Dr. Weist's work on this project was also supported by cooperative agreement U45 MC 00174-10-0 from the Office of Adolescent Health, Maternal and Child Health Bureau (Title V, Social Security Act), Health Resources and Services Administration, with co-funding by the Center for Mental Health Services, Substance Abuse and Mental Health Services Administration. Sincere appreciation is extended to Robin Warren, Marion Odubiyi, Tanya Bryant, Tonya Genison Price, and Kathy Ferguson for their significant assistance to the successful completion of the study.

For more information on this study or for a full copy of the study final report, contact Mark D. Weist, Ph.D., Professor and Principal Investigator at the University of Maryland, Department of Psychiatry, 737 W. Lombard Street, Baltimore, MD 21201;

mweist@psych.umaryland.edu; 410-706-0980, or Jennifer Pollitt Hill, M.S.W., Executive Director, the Maryland Coalition Against Sexual Assault (MCASA) at 1517 Gov. Ritchie Highway, Suite 207, Arnold, Maryland 21012; info@mcasa.org; www.mcasa.org; 410-974-4507. 


\section{Final Report}

\section{Sexual Assault in Maryland: The African American Experience*}

Mark D. Weist, ${ }^{1}$, Jennifer Pollitt-Hill, ${ }^{2}$ Linda Kinney, ${ }^{1}$ Yaphet Bryant, ${ }^{1}$ Laura Anthony, ${ }^{1}$ and Jennifer Wilkerson, ${ }^{1}$

Division of Child and Adolescent Psychiatry, University of Maryland School of Medicine ${ }^{1}$ Maryland Coalition Against Sexual Assault ${ }^{2}$

October 25, 2006

*Supported by the research grant \#2003-MU-MU-0001 from the National Institute of Justice, U.S. Department of Justice, 2003-2006. Dr. Weist's work on this project was also supported by cooperative agreement U45 MC 0017410-0 from the Office of Adolescent Health, Maternal and Child Health Bureau (Title V, Social Security Act), Health Resources and Services Administration, with co-funding by the Center for Mental Health Services, Substance Abuse and Mental Health Services Administration. Sincere appreciation is extended to Robin Warren, Marion Odubiyi, Tanya Bryant, Tonya Genison Price, and Kathy Ferguson for their significant assistance to the successful completion of the study.

\section{PURPOSE, GOALS, AND OBJECTIVES}

In response to the National Institute of Justice solicitation Broadening Our

\section{Understanding of Violence Against Women From Diverse Communities, the University of}

Maryland School of Medicine in collaboration with the Maryland Coalition Against Sexual

Assault conducted a needs assessment of African American and Caucasian female residents of

Maryland who have been sexually assaulted. This project, Sexual Assault in Maryland: The

African American Experience broadens our understanding of the needs of African American

women who are sexually assaulted, their use of traditional services and resources for sexual

assault, and their use of alternative resources. We hope that the findings will assist in improving

services for African American women who are sexually assaulted in the State of Maryland, will

help to fill a critical research gap, and will help to improve policies to address this significant

issue on state and national levels.

Health care professionals and researchers are increasingly viewing sexual assault as a

public health crisis (Crime Victim Research and Treatment Center, 1992; Russell \& Bolen, 2000; 
Schafran, 1996; Von et al., 1991). Using a definition of rape that includes forced vaginal, oral, and anal sex, 17.7 million women and 2.8 million men have been raped as a child and/or adult (Tjaden \& Thoennes, 2006). Sexual assault is associated with physical and psychological morbidity including pain, depression, Post-Traumatic Stress Disorder, and anxiety (Ackerman et al., 1998; Boney-McCoy \& Finkelhor, 1995; Campbell \& Raja, 2005; Ellis, 1983; Kaukinen \& DeMaris, 2005; Koss, 2005; McFarlane et al., 2005; Roth \& Lebowitz, 1988; Ullman \& Filipas, 2001), and each episode of such an offense has the potential to produce multidimensional negative effects upon the well being of the victim. In addition, the suicide risk for victims of sexual assault far surpasses that of non-victims (Kilpatrick et al, 1985; Resick, 1987). The scope of the problem underscores the need for broad-based investigation of the strengths and weaknesses of our current service system for sexual assault victims.

Literature exploring post-assault responses, consequences, and barriers to reporting and help seeking behavior among different ethnic groups is limited (National Research Council, 1996). For example, Reid and Kelly (1994) identified 277 abstracts on psychological research on rape for the period 1987-1994. Only 7 of these included the keyword “African American” or “black” women (Reid \& Kelly, 1994). Research paradigms directed at the study of the "universal woman” have focused on white middle class populations (Reid \& Kelly, 1994). A number of issues have been noted in the literature on research on minority populations.

The most common use of race in published journals has been as a filter in sample selection and as a “control” variable in regression analysis (LaVeist, 2000). In addition, minority group status is often equated with lower socioeconomic status despite variation in social strata among minority population groups (Lillie-Blanton \& LaVeist, 1996). Conclusions drawn from this literature strongly suggest a paradigm shift from research which merely describes racial 
differences in health to research which attempts to elucidate differences in experiences in access to services and quality of services.

Related to the above themes, the goals and objectives of this research study were to:

Goal 1: To better understand the problem of sexual assault among African American women in Maryland.

Objective A: To assess the type and intensity of sexual assault among African American women. Goal 2: To assess African American women's use of available resources in response to sexual assault.

Objective A: To assess reporting by African American women of sexual assault to police and potential barriers to reporting.

Objective B: To assess medical and psychological care received by African American women after sexual assault and to assess potential barriers to this care.

Objective C: To assess the possible influence of race/ethnicity on the receipt and quality of medical and psychological care following sexual assault.

Goal 3: To explore the use of alternative sources of care (e.g. from family/friends, faith communities, medical and mental health personnel) by African American women who have been sexually assaulted.

\section{LITERATURE REVIEW}

Epidemiological Findings

According to the National Crime Victim Survey, African Americans are more likely than persons of other races to be victims of violent crimes (Catalano, 2004). Using Bureau of Justice statistics, Smith and colleagues (1999) reported that African American residents in urban areas have experienced a higher rate of violent crime than urban whites. Reported rates of sexual 
assault for African American women have varied. Rennison (2001), using Bureau of Justice statistics found that between 1993-1998, the average annual victimization rate for rape and sexual assault was 3.7 per 1,000 persons aged 12 and over for African Americans, and 3.1 per 1,000 for whites.

The National Violence Against Women Survey found that the lifetime rate of rape and attempted rape for women was 18.8\% for African Americans and 17.7\% for whites (Tjaden \& Thoennes, 1998). Wingood and DiClemente (1998) reported that rates of rape are higher among African American women than rates for women from other racial/ethnic groups. The National Crime Victim Research and Treatment Center (1992) reported that African-American women were sexually assaulted at rates almost three times higher than that of white women.

In addition, one study found that African American women reported slightly more incidents by strangers (Wyatt, 1992), and another study found that Black women had the highest incidence of forced intercourse through verbal threats (Kalof, 2000). However, using findings from the National Crime Victim Survey, Catalano (2004) reported that African Americans and Whites experienced similar rates of rape/sexual assault. Similarly, some researchers have found that race was not related to likelihood of sexual assault (George, Winfield, \& Blazer, 1992; Priest, 1992). Thus, findings are mixed regarding the incidence of rape and sexual assault among African Americans versus other racial/ethnic groups. Sociocultural Factors and the Reporting of and Response to Sexual Assault Holtzman (1996) posits that to guide a rape survivor through the recovery process, it is necessary to know the meaning and consequences of rape in the specific sociocultural context of the survivor's community. Providing some historical and social context is necessary for understanding the sexual assault experience of African American women. Race has a profound 
social meaning, rooted in history but with contemporary consequences (LaVeist, 2000). Specifically, a review of the literature by Fonow and colleagues (1992) offers a concise perspective on racism and rape. During slavery, the slave owner and his surrogates had carte blanche to the African enslaved woman's body. Rape was a form of terror and social control with no legal consequences. After slavery, most African American women worked as domestic servants in the homes of Caucasians, and were often repeatedly raped by the men in the families for which they worked, with no legal repercussions. In essence, the rape of African American women was an unpunished crime for centuries. As a consequence, today racial myths about rape persists; the most relevant being “African American women cannot be raped.” Myths about rape as a whole persist contributing to low reporting rates.

In general, rape is an underreported crime; it is estimated that only $36 \%$ of rapes are reported to police (Rennison, 2002). Washington (2001) examined the disclosure patterns of African American women sexual assault survivors. The major barriers to disclosure and helpseeking were: 1) perceived racism and sexism in the legal system, 2) perceived racism of health care providers, and 3) an overall struggle with the structural inequalities. Results identified the following as factors influencing disclosure and/or help-seeking behaviors among African American women: 1) sexual orientation, 2) socioeconomic status, 3) nature of assault, availability of services, 4) prior negative experiences, 5) perceived need to protect African American males from legal prosecution, 6) perceived racism, and 7) religion/spirituality. Additional factors that influenced disclosure were noted such as internalization of the "Black Superwomen” myth, self blame, prior consensual sex with the perpetrator, and fear of sexual history being revealed. 
Further, in a study of African American and Caucasian women sexual assault survivors, findings suggest that African American women were less likely to disclose the assault than Caucasian women (Neville, Heppner, \& Clark, 2004). In addition, African American women were more likely to believe that overall, African American women were at a greater risk for being sexually assaulted than Caucasian women and that their living circumstances placed them at a greater risk for sexual victimization than Caucasian women (Neville, Heppner, \& Clark, 2004). In another study, Wyatt (1992) found that African American women were significantly more likely than White women to offer explanations about their sexual assault victimization that involved risk factors in their living circumstances. Other possible cited reasons for the low reporting rates of sexual victimization by African American women include perceived insensitivity by police to African American women and reluctance to report African American men because of perceived racial bias (Karjane, Fisher, \& Cullen, 2002; Neville \& Pugh, 1997; Thompson \& West, 1992; Wyatt, 1992).

Many African Americans mistrust police because of personal experiences of harassment or awareness of disproportionate arrests and incarcerations of Black men (National Institute of Justice, 2001; Robinson, 2002). Women of color must often contend with tension between their needs for justice and their felt obligations to buffer tension in the criminal justice system (Rozee \& Koss, 2001). Concomitantly, biases related to sexual assault perceived by African American women to operate in legal systems are supported by some research studies. For example, LaFree (1981) found that officials were more likely to file felony charges if a sexual assault involved an attack by a Black male against a White female, and also found that Black men accused of assaulting Black women were less likely to be arrested. Campbell (1998) found that legal cases of women of color who were raped by White men were more likely to "fall apart" during 
processing. In a study of sexual assault victims that were 51\% African American and 37\%

Caucasian, Campbell and colleagues (2001) found disproportional rates of case prosecution, with $70 \%$ of cases involving Caucasian women prosecuted, and only 30\% of cases involving African American women prosecuted.

Further, in a mock trial study, participants with high scores for authoritarianism were more likely to agree with a White victim's rape claim against a Black defendant than a Black victim’s claim against a white defendant (Landwehr et al., 2002). In another mock trial study, both Black and White defendants were rated as more guilty when the victim's race differed from their own (Hymes \& Leinart, 1993).

\section{Sociocultural Factors and Access to and Quality of Care}

Our review yielded conflicting studies regarding access to care and quality of care. For example, Resnick and colleagues (2000) found that African Americans were more likely to obtain post-rape medical care than Caucasians. However, Campbell and Bybee (1997) found that African American women were less likely to receive follow up care, treatment for sexually transmitted diseases or pregnancy, emergency contraception, and information related to sexual assault. Dearwater and colleagues (1998) found that rates of acute trauma from abuse were significantly greater for African Americans than for Whites or Hispanics.

In another study, Campbell and colleagues (2001) found that women of color were four times less likely to have their injuries treated than were White women, and six times less likely to receive follow up care than White women. In addition, White women were more likely than ethnic minorities to receive HIV information. More recently, Campbell and Raja (2005) examined a sample of predominantly low-income African American women veterans and reservists who were sexually assaulted as adults $(\mathrm{N}=104,77 \%$ African American). Results 
indicated that most of the survivors who sought help in military or civilian systems (medical or legal) felt guilty, depressed, anxious, distrusted others, and were hesitant to seek further assistance.

In a study of 155 African American adults, victims generally endorsed the need for counseling following a rape and expressed positive attitudes regarding treatment outcomes (Thompson \& West, 1992). Additionally, Frazier, Rosenberger, and Moore (2000) found that only $9 \%$ of 522 sexual assault victims seen in emergency room settings returned for follow-up counseling and that young ethnic minority woman who tended to be more distressed were least likely to seek follow-up counseling. However, in the study by Campbell and colleagues (2001) consisting of 51\% African American and 37\% white women, only 31\% of those who contacted a mental health professional were of ethnic minority background. In addition, of those who contacted a rape crisis center, 91\% were White and only 9\% were ethnic minority. Furthermore, sexual assault survivors in general may prefer less formal sources of support following assault such as that provided by clergy (Cheston, 1993; Fouque \& Glachan, 2000). African American women may desire to avoid further stigmatization of being treated for “mental illness” (Barbee, 1999) and may be more likely to turn to family, friends (Robinson, 2002; Wyatt, 1992) and clergy (Sims, 2002; Young, Griffith, \& Williams, 2003) for assistance. Priest (1992), in a study of 168 victimized African American women found that only 32 received more formal mental health counseling, and only three indicated that the counseling directly rated to sexual victimization. However, in Ullman and Filipas’ (2001) examination of correlates of formal and informal help-seeking behaviors of sexual assault victims, results suggested that ethnic minority women received more emotional support from mental health professionals and physicians than from other sources of support. Similarly, Diala and colleagues 
(2001), using data from the National Co-morbidity Survey, found that African Americans reported more positive attitudes than Whites toward seeking mental health services, but were less likely to actually use them. After utilization, their attitudes were found to be less positive than those of Whites. For Major Depressive episodes, African Americans had significantly lower odds of using mental health services than Whites.

In a study of victim assistance workers, African American victims were perceived as less credible and as more responsible for the assault than White victims (Winkel \& deWinter, 1995). For African American victims, the consequences of the event were considered to be less serious, while the available evidence was seen as less convincing for them. The occurrence of the event was significantly more often attributed to the African American person’s behavior.

Further, Nagel, Matsuo, McIntyre, and Morrison (2005) examined a community sample of African American and White adults concerning their attitudes toward victims of rape. Results suggest the existence of a complex interaction of demographic variables such as age, race, gender, income, education, and religion. More specifically, results suggested that: 1) Females held more sympathetic attitudes toward rape victims than males; 2) African Americans held less sympathetic attitudes toward rape victims than Whites; 3) African American men held the least sympathetic attitudes towards rape victims than did other groups; 4) younger respondents held more sympathetic views of rape victims than did older respondents; and 5) respondents with higher levels of education and income held more sympathetic attitudes towards rape victims than those with lower levels of education and income.

These studies provide a review of key variables explored so far in research on experiences of sexual assault victims of varying racial/ethnic backgrounds. They helped to 
inform the goals, objective and measurement approach of the study, which is presented in the following.

\section{METHODOLOGY}

\section{Advisory Panel}

All aspects of the project were coordinated by the principal investigator (PI; M. Weist), and the MCASA Director (J. Pollitt-Hill). The PI and the MCASA Director worked very closely with an Advisory Panel developed for the project, including six state and community leaders with respective backgrounds in clinical psychology, domestic violence, treatment and support to sexual assault victims, law enforcement, community organizing, and advocacy. All panel members were African American with two males and four females. The Panel held meetings in person five times, in December, 2003; June, 2004; October, 2004; October, 2005; and March, 2006 to plan for various aspects of study development, implementation and interpretation of findings. Panel members were also in communication with the PI and MCASA director through email and by phone as indicated.

Data were gathered by two methods: (1) focus groups with MCASA member program staff and other community service providers, and (2) face-to-face interviews with African American and Caucasian female residents of Maryland who were sexually assaulted.

\section{Focus Groups}

Focus groups and training sessions were held with the four professional groups originally identified to assist with study recruitment efforts - rape recovery programs (including both SA only and dual SA/DV programs), domestic violence only programs, sexual assault forensic exam programs and historically black colleges and universities in Maryland. On several occasions, as in the case of historically African American college and university (HBCUs) counseling center 
personnel, it was challenging attempting to schedule a focus group for all personnel in a particular group, so individual interviews were conducted over the phone and in person with several representatives of HBCUs, hospitals, and rape crisis centers. These four groups were part of the original proposal and study design approved by NIJ. Training sessions were held with each of these four recruitment partners to explain the context, history, and purpose of the study as well as discuss ethical issues relating to human research studies, referral/recruitment protocol and marketing materials. The purpose of the focus groups was to gain information from our recruitment partners regarding perceived barriers to services for African American survivors, not to formulate hypotheses.

The list of five focus group questions was constructed by project researchers with consultation from sexual assault victims and advocates. Topics covered included unique issues and needs of African American women who have been assaulted, and issues of the agency (e.g., strengths, problems) in assisting African American sexual assault victims. Each focus group participant received a nametag. Instead of the participant's name, the nametag had a number so that participant's answer was not recorded by name. Notes were taken by a research assistant and project coordinator and sessions were audio-taped. All information gathered during focus groups was kept confidential and once transcribed, all audiotapes were destroyed.

\section{Focus Group Recruitment and Informed Consent}

Rape crisis center representatives and the other community service provider representatives received a letter informing them that a focus group was going to be conducted at the end of their study training session and asking them for their participation. They were informed about the purpose of the focus group, the topics to be covered, and the length of the session. 
Informed consent forms were given to the participants before the focus group was conducted. Research staff emphasized to participants that they were under no obligation to participate in the focus group, and that choosing not to participate would have no adverse effects to them in their employment or with the study. Research staff then went over the informed consent form and responded to questions from participants, which were limited.

Each focus group utilized two facilitators and two note takers. The number of participants in the focus groups ranged from 4 to 10 with an average of 7 participants per group. The focus group sessions were taped and notes were taken. The tapes were transcribed, and transcriptions were augmented by written meeting notes. These augmented transcriptions were then used by research staff to identify key themes in focus groups. For these qualitative analyses thematic conceptual matrices were developed. Data were analyzed following the process suggested by Marshall and Rossman (1999): An iterative process was undertaken, wherein (1) themes were sorted by a priori categories, (2) a priori and emergent hypotheses were tested against augmented focus group transcripts; and (3) alternative explanations were considered and tested against the transcripts.

\section{Focus Group Findings}

As mentioned, focus group questions and key themes are presented in Appendix A. For Question 1, regarding needs of African American sexual assault victims, key themes included enhancing access to services (e.g., through transportation, financial assistance), removing stigma from therapy and medication services, and enhancing relevant educational programs (e.g., on safety issues, acquaintance and statutory rape). For Question 2, regarding experiences with the legal system, key themes included problems with response to victims who had been using drugs and/or alcohol, experiencing racism by police officers, and reluctance to report sexual crimes of 
African American males. For Question 3, on unique issues to the use of available resources by African American women, themes included problems with acceptance of mental health services by these women, and that mental health issues are a "way of life," that they can take care of themselves. For Question 4, on experiences in outreach to African American victims, themes included perceptions that outreach is generally limited, that “concrete” services (e.g., for housing, employment) are more of a concern than less concrete (e.g., counseling), and that in challenging situations (e.g., in public housing) survivors may be too busy taking care of their own circumstances to participate in outreach services. For Question 5, on recommendations for the State of Maryland to improve services, themes included enhanced resources for public awareness, increased resources for alternative methods of healing (e.g., art, drama, meditation), and better training for police officers to competently work with victims.

\section{$\underline{\text { Interviews }}$}

\section{Recruitment of Study Participants}

Criteria for inclusion in the interview component of the study included: (1) African American or Caucasian female, (2) age 18 and over, (3) resident of Maryland, and (4) victim of sexual assault. There were four streams of recruitment for the interview portion of the study: (1) victims receiving services at one of 18 rape crisis centers located throughout the state of Maryland, (2) community outreach sessions conducted by rape crisis center community educators, (3) through community service providers, including those working in domestic violence centers, forensic nurse examiners (SAFE programs), probation and parole offices, reproductive health centers, county health departments, community services agencies, HBCUs and local colleges, and (4) through three detention centers housing female inmates. Please note that we did not originally plan to recruit participants from detention centers. However, in a 
meeting held in October, 2004, the Advisory Panel made a strong recommendation to recruit and conduct the study with incarcerated women. This recommendation was based on findings that these women have elevated rates of sexual assault. For example, in Brown, Miller, and Maguin's (1999) review of the literature of sexual assault and incarcerated women they found that the rates of physical abuse or sexual assault among these women ranged from $43 \%$ to $75 \%$, rates significantly higher than those for other populations (see Rennison, 2001, 2002).

(1) Rape crisis centers. Each of the rape crisis centers (referred to in Maryland as Sexual Assault Recovery Centers) were asked to identify and refer female victims for an interview. A designated representative from each rape crisis center attended a training session to receive information about the study. Each clinician at the rape crisis centers attempted to recruit both African American and Caucasian clients of non Hispanic backgrounds. Clinicians gave prospective participants a flier and described the study by covering the following topics: purpose of the study, areas covered in the interview, length of the interview, compensation for participants, and assurances of confidentiality and the right not to participate in the study. If the client agreed to participate, she called the MCASA site coordinator to schedule an interview. If possible, the interview was scheduled to coincide with the client's next visit to the crisis center.

(2) Community educators. Rape crisis center community educators made an announcement about the study when they spoke to adult groups about sexual assault. They also had fliers and question and answer sheets available. For community members who expressed an interest, the study was described and recruitment proceeded as above.

(3) Community service providers. Fliers and posters about the study were displayed in reception areas and offices of various community service providers. A designated representative from each provider organization was identified and trained about the study by the MCASA site 
coordinator. This representative informed members of their staff so that they would be able to answer potential participant questions and encourage them to call study staff. Information about the study and reminders were included in provider newsletters. Counselors at historically black colleges made an announcement about the study at on-campus presentations about sexual assault. They also had fliers and question and answer sheets available in their offices. For these groups, procedures for providing information about and recruiting participants into the study followed those reviewed above.

(4) Forensic Nurse Examiners. A representative from each Sexual Assault Forensic Exam program in Maryland was identified and educated about the study. This representative informed members of their staff and were given fliers and question and answer sheets to distribute to patients. For patients who expressed an interest, the study was described and recruitment proceeded as above.

(5) Detention Centers. For the three participating detention centers, an MCASA staff person went to the centers and gave a presentation on sexual assault, its impact, and available services to assist in recovery. At the end of this presentation, information on the study was given out, and procedures for confidentially expressing interest in participation with on-site counselors were established. Participants in detention centers then expressed interest in participation to onsite counselors who worked out logistics of interviewing with MCASA staff.

Sites where interviews for the study were conducted are presented in Appendix B.

\section{Interview Instrument}

The interview instrument was designed specifically for this study, building on the instrument used from our prior research (Dantzler, Weist, Kinney, \& Monroe, 2003). Some questions were modified based on feedback by participants of study forums and MCASA study 
collaborators. Other questions were added that were unique to the goals and objectives of this study. The interview instrument was reviewed extensively by MCASA staff and members of the MCASA Women of Color Network, as well as members of the study Advisory Panel and project officers from the National Institutes of Justice (NIJ). Changes to the instrument were made based on this feedback. The final measure includes 110 items including items in the following categories: Personal Demographics (7 items), Details of the Sexual Assault (23 items), Medical Care (19 items), Law Enforcement (11 items), Prosecution/Court Process (11 items), Sexual Assault Center Services (22 items), Other Counseling Services (9 items), and Recommendations for Improvement (8 items). Wherever possible, interview questions provided specified options for responses versus open ended questions, with some yes-no answers, and some Likert ratings. The Interview Instrument is presented in Appendix C.

\section{Interviewers}

Four women, three with masters degrees and one with a bachelors degree in a mental health or public health discipline were recruited as interviewers for the project. Consistent with recommendations to match interviewers and interviewees on gender and race for sensitive topics such as sexual assault (National Institute of Justice, 2001; Russell \& Bolen, 2000; Winwood \& DeClemente, 1998; Wyatt, 1992), three of the interviewers were African American, one was Caucasian, and race of interviewer always matched for African American interviewees. The four interviewers underwent a day-long training coordinated by University of Maryland on effective interviewing of sexual assault victims and use of the interview instrument. Weekly meetings held at MCASA ensured that interviewers were adhering to standard procedures in collecting the interviews and in empathically conducting the interview and in supporting victims.

\section{Interview Process}


Interviews took place at each of the 18 rape crisis centers located throughout Maryland, at three correctional facilities, and in community sites from January 1, 2004 through July, 2005. Interviews took between 45 minutes and 2 hours and 15 minutes. The length of interviews varied for many reasons, with a key dimension being whether particular services were received. For instance, if the respondent had not reported her assault to the police, she did not answer extensive questions about her experience with the police. Two additional reasons for variation in the length of interviews were case management and service needs presented by participants (which interviewers would attempt to assist with following completion of the interview questions), and the sensitive, at times emotion evoking nature of the interview process, which was handled sensitively by the interviewers. Please note that of the total of 224 interviews (corresponding to the number of participants in the study) that were conducted, no participant offered any concerns or complaints about the interview content or process, and a number of them expressed feelings that the interview was supportive, even therapeutic.

At the completion of the interview, the interviewer gave the participant an unmarked sealed envelope that contained their \$10 cash compensation. As mentioned, some participants presented service needs, and if this was the case, after the formal interview, research staff attempted to assist interviewees in connecting to relevant services in their local community, particularly the local sexual assault recovery center.

\section{Human Subjects}

All study procedures were approved by the University of Maryland School of Medicine (UMSM) Institutional Review Board (IRB), with initial approval in December, 2003. Based on an Advisory Panel recommendation made at the October, 2004 meeting to extend the study into detention centers, this was pursued with final UMSM IRB approval to conduct the study in these 
centers provided in April, 2005. The decision to conduct the study at these centers was based on the recognition of the significant exposure to sexual assault among incarcerated women (Browne, Miller, \& Maguin, 1999), and an opportunity to move forward through the NIJ grant and MCASA connections to detention centers. A total of 63 women (35 African American, 28 Caucasian) were interviewed at three detention centers in Maryland (in Montgomery, Prince Georges, and Washington counties) between April and July, 2005.

Study staff did not contact the potential participant at their home or place of business unless the participant had directed them to do so. All attempts were made to interview the participant at the local rape recovery center (or detention center for those participants) with the ideal of letting them know that such a facility exists and helping them make an initial connection to it. However, in cases where participants found it more convenient to be interviewed at a local community service center, those needs were met. Regardless of where the interview took place, subjects were interviewed in a private room. Interviewers all had experience working with victims of sexual assault. After obtaining informed consent and prior to beginning the interview, the interviewer acknowledged to the victim participant that talking about their experience may be difficult. The interviewer let the participant know that they may take a break at any time and that counselors are available if they think it would be beneficial to speak to one in person at the rape recovery center or by telephone if the interview was conducted at a community service center. The interviewer and/or available on-site counselor debriefed the participant after the interview. If the study participant was currently receiving services from that crisis center, their counseling session took place after the interview whenever possible. Data collection was anonymous, with no personal identifiers recorded other than age and race. 
Under no circumstances was a client pressured in any way to participate in the study. The voluntary nature of the study was emphasized and assurance was given that declining to participate would be associated with no negative consequences at the rape crisis center. Participants were told that they could decline to answer any question and could stop the interview at any time. The interviewer reviewed the informed consent form with the prospective participant and answered any questions. Once the informed consent document had been signed, a copy was made for the participant to keep. The interviewer kept the original copy of the informed consent in a locked file cabinet at the MCASA central office until it was delivered to research staff at the University of Maryland. Consent forms were stored separately from completed interview documentation.

Please note that experiences of victims who participated in this study were generally positive, and many of the victims expressed appreciation for participating in the study, expressing that it was therapeutic for them to do so.

\section{Logistical Challenges and Study Limitations}

In our proposal to NIJ we calculated that around 500 study participants would be necessary for the study to achieve adequate power, as presented in the proposal: “A study of this size will have excellent power to detect small differences between Caucasian and AfricanAmerican women with respect to the study outcomes. For instance, Hypothesis 1A1 states, 'African American women will be more likely to experience sexual assault by a stranger than Caucasian women.' If the proportion with a history of sexual assault by a stranger in the two groups were 7\% for Caucasians and 18\% for African Americans (as found in the SNAP study), then a study of this size will have $92 \%$ power to detect such a difference (based on a two-sided .05-level Pearson Chi Square test). As another example, Hypothesis 1A2 states, 'African 
American women will be more likely to experience a greater intensity of assault (having a weapon used against them, greater force) than Caucasian women.' The interview instrument asks the subject what took place during the assault. Subjects will receive an intensity of attack rating between 0-6. If the mean intensity score differs between the two groups by 0.67 points, and the standard deviation of the intensity scores is 2.0 (a very conservative estimate given this is a score that takes values between 0 and 6), then a study of this size will have $96 \%$ power to detect a difference (based on a two-sided test at a probability level of .05).”

Unfortunately, we did not achieve the targeted sample size of 500 for a number of reasons. First, we did not anticipate how labor intensive and difficult participant recruitment would be. Beginning in January, 2004, many strategies were used to publicize the study, including personal conversations with directors of all 18 Maryland rape crisis or sexual assault recovery centers; presentations at local colleges, HBCUs, community centers and churches; posting of the study announcement on the MCASA website; radio interviews and public service announcements; and broad dissemination of over 3000 flyers about the study throughout the state of Maryland. These efforts broadened and intensified as the study progressed, and the number of women expressing interest in the study per month also progressed (from around 5 per month in early months to around 20 per month in latter months). However, in spite of these efforts recruitment was significantly more difficult than imagined.

The majority of interviews (96 of 224) were held at the local rape recovery center nearest the study participant in an effort to provide the participant with crisis response services if needed after the interview and/or to provide linkages to community resources outside of the interview session. Although interviews were held at rape recovery centers, participants were recruited from a number of sources and were not necessarily clients of the rape recovery center. 
Participants did not know that the interview would be held at a rape recovery center until they called to express interest in the study and were properly screened as eligible for the study. The location of the interview was known to the participant only at the point at which the interview appointment was scheduled. Therefore the possible barrier of conducting interviews at rape recovery centers would only impact those clients that scheduled appointments at rape recovery centers but did not show for the interview. These are the only study participants who would have had the opportunity to self-select out of going to a rape recovery center.

In addition, interviews were not exclusively held at rape recovery centers. Sixty-two (62) of the interviews were held at a local social service agency where the study participants were already receiving services. Each of these participants were offered the opportunity to interview at the rape recovery center, but preferred the social service agency due to convenience. One (1) interview was held at a university counseling center at the preference of the study participant. No study participant was declined an interview because they did not want to be interviewed at a rape recovery center. Location of the interview was not a universal barrier to study participants.

Furthermore, we underestimated the logistical challenges in conducting interviews around the state of Maryland. During active data collection, usually on any given day, two interviewers from MCASA were available. Initially, they responded to individual interview requests from all around the state, sometimes traveling all the way to Western Maryland or the Eastern shore, with drive times up to four hours in one direction. MCASA staff tried to connect interviews together in similar regions of the state but this was often hard to do (e.g., one person in the Western part of the state would be available one day, but another person expressing interest would not be available that day). A total of 286 interviews were scheduled based on phone contact with MCASA staff. Of these, there were 29 no shows, 20 cancellations, 6 who 
called to reschedule but then did not show, 6 who did not meet criteria to participate, and 2 who did not complete the interview and were referred to a counselor instead. Thus, $22 \%$ or around one in five scheduled interviews did not occur.

Related to these factors, often the interviewers were only able to complete a few interviews each per week. Complicating these logistical challenges was the interview itself, which took on average 90 minutes, with social and supportive time at the front and back ends. In spite of these logistical demands, and related to a very strong recommendation from the study's Advisory Panel, we maintained the commitment to only doing face-to-face interviews (e.g., NOT by phone), related to the sensitive nature of the interview and the likely service and support needs of interviewees.

Related to these recruitment and logistical challenges, and through in-kind resources of both the University of Maryland and MCASA, we extended interview data collection beyond its original end date of January, 2005 by six months, to July, 2005. Yet, in spite of these efforts we were able to obtain less than half of the anticipated sample - 224 instead of 500. We are grateful to NIJ for the privilege of conducting this study and convey our disappointment in not completing the study as planned. The implication and major caveat is that one can legitimately argue that the study is underpowered, and more significant differences would have been detected if we would have achieved the desired sample size of 500. However, due to the nature of the study data, the many constructs being investigated, and the lack of prior research for some of these constructs, identifying parameters for power analyses is difficult. As such, for some measures, power may actually have been adequate but it is not possible to definitively determine this. We considered and attempted to balance a number of these factors in making interpretative comments about study findings in the Discussion section. This concern notwithstanding, this 
study also yielded important process findings on the resources and approaches needed to successfully and sensitively involve victims of sexual assault in research on their experiences (elaborated on in the Discussion).

\section{RESULTS}

\section{Demographics}

Interviews were collected from 224 women, however, one woman declined to label herself as either African American or Caucasian, and another indicated she was “mixed.” Responses from these participants were included in analyses for the total sample, but obviously are not included in analyses regarding racial/ethnic differences $(\mathrm{N}=222)$. Please note that while the interviewers attempted to ensure completion of all items, a number of the items are not relevant to particular subjects (e.g., if a service was not received), and some items were otherwise not completed. Sixty-two percent of the women were African American (N=139), and 37\% were Caucasian ( $\mathrm{N}=83)$. Please note that since the study involved a new interview measure, that frequently involved categorized or yes-no responses, non-parametric statistical analyses were used in interpreting all data gathered from the interview portion of the study. There were no significant differences between the African American and Caucasian women in their age, level of education, nor household income level. Data on age, educational level, and income for African American and Caucasian participants are presented in Table 1.

Table 1. Demographic Data for Age, Education, and Income

$\begin{array}{lcccc} & \text { Mean } & \text { SD } & \text { Minimum } & \text { Maximum } \\ \text { Age } & 37.0 & 10.3 & 18.0 & 70.0 \\ \text { African American } & 37.1 & 10.1 & 18.0 & 70.0 \\ \text { Caucasian } & 36.7 & 10.6 & 20.0 & 64.0\end{array}$




\begin{tabular}{|c|c|c|c|c|}
\hline Education level & $\begin{array}{c}2.7 \\
\text { (2=high school graduate, } \\
3=\text { trade or technical school) }\end{array}$ & 1.7 & $\begin{array}{l}\text { "Some high } \\
\text { school" }\end{array}$ & "Doctoral degree" \\
\hline African American & 2.58 & 1.7 & & \\
\hline Caucasian & 2.84 & 1.5 & & \\
\hline Household income & $20,794.3$ & $27,578.4$ & 0 & $125,000.0$ \\
\hline African American & $19,952.5$ & $26,764.9$ & & \\
\hline Caucasian & 22,381 & $29,119.4$ & & \\
\hline
\end{tabular}

Participants represented a variety of socioeconomic backgrounds. More than half of the participants were Single $(N=123)$, while the remainder were predominately Separated/Divorced $(N=53)$ or Married $(N=37)$. A number of participants also received public assistance $(N=80)$. The forms of public assistance included WIC, Medical, Housing, Income, and Other. Eleven participants received support from the Special Supplemental Nutrition Program for Women, Infants, and Children (i.e. WIC), while 40 participants received Medical Assistance. A smaller number of participants also received assistance to pay for Housing $(N=13)$ and to supplement their Income $(N=12)$. Table 2 contains a complete summary of the different forms of assistance participants received.

Table 2. Different Forms of Public Assistance for Those Receiving It ( $\mathrm{N}=79$ )

Type of Public Assistance:

Receives WIC

African American

Receives medical assistance

African American 
Receives housing assistance

African American

Caucasian

Receives income assistance

African American

Caucasian

Receives other public assistance

African American

Caucasian
9

16.4

17.4

10

1

4.3

45

81.8

15

65.2

Around $43 \%$ of the women $(\mathrm{N}=96)$ were interviewed in rape crisis centers, $28 \%(\mathrm{~N}=62)$ were interviewed in other community centers, and another $28 \%(\mathrm{~N}=63)$ were interviewed in detentions centers, with 1 participant interviewed at the University of Maryland. Table 3 provides a more detailed description of the number of participants interviewed at the four types of settings (see Appendix B for a more specific breakdown of sites where interviewing occurred). Again, please note that for analyses exploring racial differences, the $\mathrm{N}$ is 222 . Table 3. Number of Participants Interviewed by Setting and Race

\begin{tabular}{|c|c|c|c|c|}
\hline & & \multicolumn{2}{|c|}{ Race } & \multirow[b]{2}{*}{ Total } \\
\hline & & $\begin{array}{c}\text { African } \\
\text { American }\end{array}$ & Caucasian & \\
\hline \multirow[t]{4}{*}{$\begin{array}{l}\text { Center where } \\
\text { interviewed }\end{array}$} & $\begin{array}{l}\text { Rape Crisis } \\
\text { Center }\end{array}$ & 54 & 42 & 96 \\
\hline & $\begin{array}{l}\text { Social Service } \\
\text { Agency }\end{array}$ & 50 & 12 & 62 \\
\hline & Detention Centers & 35 & 28 & 63 \\
\hline & University & 0 & 1 & 1 \\
\hline Total & & 139 & 83 & 222 \\
\hline
\end{tabular}

In addition, participants resided in different parts of the state. While the majority of participants lived in Central Maryland $(N=150)$, there were still a number of participants who came from the Western $(N=35)$, Southern $(N=23)$, and Eastern $(N=9)$ parts of the state. 
Demographic information revealed that the number of participants living in urban $(N=101)$ and suburban $(N=89)$ areas was almost equal, with the remaining participants living in rural areas ( $N=33)$. Participants reported the ethnicity of the perpetrators to be African American $(N=145)$ or White $(N=58)$, which accounted for ninety-one percent of the perpetrators in this study. The ethnicity of the other perpetrators was identified as Other $(N=7)$, Hispanic $(N=6)$, Asian/Pacific Islander $(N=3)$, Unknown $(N=3)$, or American Indian/Alaska Native $(N=1)$. Table 4 provides a breakdown of race/ethnicity for victims and perpetrators.

\section{Table 4. Race/Ethnicity of Victims and Perpetrators}

\begin{tabular}{|c|c|c|c|c|c|c|c|c|c|}
\hline \multirow{2}{*}{\multicolumn{2}{|c|}{$\begin{array}{l}\text { Victim's } \\
\text { Race/Ethnicity }\end{array}$}} & \multicolumn{7}{|c|}{ Race/Ethnicity of perpetrator } & \multirow[b]{2}{*}{ Total } \\
\hline & & White & $\begin{array}{l}\text { African } \\
\text { American } \\
\end{array}$ & $\begin{array}{l}\text { Asian } \\
\text { Pacific } \\
\text { Islander }\end{array}$ & $\begin{array}{l}\text { American } \\
\text { Indian } \\
\text { Alaska } \\
\text { Native }\end{array}$ & Hispanic & Other & Unknown & \\
\hline African & $\mathrm{N}$ & 6 & 123 & 1 & 0 & 1 & 5 & 3 & 139 \\
\hline \multirow{5}{*}{ Caucasian } & & sos & 00 & 70 & Ono & 70 & 0,0 & 020 & 10000 \\
\hline & $\begin{array}{l}\text { within } \\
\text { Race }\end{array}$ & $4.3 \%$ & $88.5 \%$ & $.7 \%$ & $.0 \%$ & $.7 \%$ & $3.6 \%$ & $2.2 \%$ & $100.0 \%$ \\
\hline & & 52 & 21 & 2 & 1 & 5 & 2 & 0 & 83 \\
\hline & $\%$ & 70 & 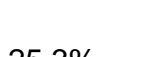 & 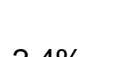 & 50 & 200 & 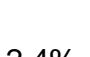 & 80 & 10000 \\
\hline & $\begin{array}{l}\text { within } \\
\text { Race }\end{array}$ & $62.7 \%$ & $25.3 \%$ & $2.4 \%$ & $1.2 \%$ & $6.0 \%$ & $2.4 \%$ & $.0 \%$ & $100.0 \%$ \\
\hline \multirow[t]{2}{*}{ Total } & & 58 & 144 & 3 & 1 & 6 & 7 & 3 & 222 \\
\hline & $\begin{array}{l}\% \\
\text { within } \\
\text { Race }\end{array}$ & $26.1 \%$ & $64.9 \%$ & $1.4 \%$ & $.5 \%$ & $2.7 \%$ & $3.2 \%$ & $1.4 \%$ & $100.0 \%$ \\
\hline
\end{tabular}

\section{Study Hypotheses}

Per our grant application to NIJ, the following hypotheses were explored for the interview portion of the study. Appendix D reviews specific items of the interview instrument that were used to explore each hypothesis.

1A: African American women will be more likely to experience sexual assault by a stranger than Caucasian women. 
1B: African American women will be more likely to experience a greater intensity of assault (having a weapon used against them, greater force) than Caucasian women.

2A1: Fewer African American women will indicate that they reported their sexual assault to police than Caucasian women.

2A2: African American women will indicate a number of racial and cultural barriers in reporting sexual assault to police.

2B1: Fewer African American women will indicate that they sought medical and psychological services following sexual assault than Caucasian women.

2B2: African American women will report a number of racial and cultural barriers in seeking and receiving medical and psychological services following sexual assault.

2C1: African American women will report receiving less medical and psychological care and will report more problems receiving this care than Caucasian women.

3: African American women will be more likely to utilize resources such as family, friends, and faith communities to deal with the aftermath of sexual assault than Caucasian women.

\section{Findings by Hypothesis}

For each hypothesis, we review general trends in findings (e.g., for the whole sample) based on our determination of whether they are of interest. When indicated, we then review analyses reviewing differences for African American versus Caucasian women.

Hypothesis 1A: African American women will be more likely to experience sexual assault by a stranger than Caucasian women.

Item number 9 of the interview instrument, pertaining to the "relationship of the person who assaulted you” was used to explore this hypothesis. Approximately 58\% of participants reported a prior relationship with the perpetrator, while around 31\% indicated perpetrators were 
strangers, and around 11\% reported perpetrators as “other” (i.e., participants were allowed to specify relationship of perpetrator if relationship was not listed as an option). Table 5 presents a breakdown of how perpetrators were labeled for participants in the study (please note that AA = African American, $\mathrm{C}=$ Caucasian).

Table 5. Report of the Relationship of Perpetrators to Victims

\begin{tabular}{|c|c|c|}
\hline & Frequency & $\begin{array}{l}\text { Percent } \\
\text { within } \\
\text { Race }\end{array}$ \\
\hline Friend-Total & 17 & 7.6 \\
\hline AA & 11 & 7.9 \\
\hline C & 6 & 7.2 \\
\hline Acquaintance-Total & 30 & 13.3 \\
\hline AA & 18 & 12.9 \\
\hline C & 12 & 14.5 \\
\hline Spouse-Total & 7 & 3.1 \\
\hline AA & 4 & 2.9 \\
\hline C & 3 & 3.6 \\
\hline Relative-Total & 36 & 16.0 \\
\hline AA & 21 & 15.0 \\
\hline C & 15 & 18.1 \\
\hline Boyfriend-Total & 21 & 9.3 \\
\hline$A A$ & 15 & 10.7 \\
\hline C & 5 & 6.0 \\
\hline Girlfriend-Total & 1 & .4 \\
\hline AA & 1 & .7 \\
\hline C & 0 & 0 \\
\hline Ex-friend-Total & 5 & 2.2 \\
\hline AA & 4 & 2.9 \\
\hline C & 1 & 1.2 \\
\hline Date-Total & 7 & 3.1 \\
\hline AA & 5 & 3.6 \\
\hline C & 2 & 2.4 \\
\hline Teacher & 1 & .4 \\
\hline AA & 0 & 0 \\
\hline C & 1 & 1.2 \\
\hline Boss & 1 & .4 \\
\hline$A A$ & 0 & 0 \\
\hline C & 1 & 1.2 \\
\hline Friend of the family & 3 & 1.3 \\
\hline AA & 2 & 1.4 \\
\hline C & 1 & 1.2 \\
\hline Co-worker & 2 & .9 \\
\hline
\end{tabular}




$\begin{array}{lcc}\text { AA } & 1 & .7 \\ \text { C } & 1 & 1.2 \\ \text { Other } & 24 & 10.7 \\ \text { AA } & 12 & 8.6 \\ \text { C } & 12 & 14.5\end{array}$

Non-parametric statistical analyses revealed that African American women were no more likely to be assaulted by a stranger than Caucasian women were (Pearson Chi-square=.646, $\mathrm{df}=1$, $\mathrm{p}=.42$ ). Hence, Hypothesis 1A was not confirmed. However, as mentioned, power issues constrain the interpretability of this finding. This caveat applies to other non-significant findings and will not be repeated. Table 6 provides data used for this analysis.

Table 6. Reports of Whether Perpetrator was a Stranger

\begin{tabular}{|ll|r|r|r|}
\hline Race & & $\begin{array}{c}\text { Perpetrator } \\
\text { was } \\
\text { stranger }\end{array}$ & $\begin{array}{c}\text { Perpetrator } \\
\text { was not } \\
\text { stranger }\end{array}$ & \multicolumn{1}{c|}{ Total } \\
\hline African American & $\mathrm{N}$ & 45 & 94 & 139 \\
Caucasian & $\%$ within Race & $32.4 \%$ & $67.6 \%$ & $100.0 \%$ \\
& $\mathrm{~N}$ & 23 & 60 & 83 \\
Total & $\%$ within Race & $27.7 \%$ & $72.3 \%$ & $100.0 \%$ \\
& $\mathrm{~N}$ & 68 & 154 & 222 \\
& $\%$ within Race & $30.9 \%$ & $69.1 \%$ & $100.0 \%$ \\
\hline
\end{tabular}

In terms of other relevant analyses, household income also was not related to whether or not the perpetrator was a stranger ( $\mathrm{t}$-test $=1.6, \mathrm{df}=215, \mathrm{p}=.11$ ), nor was level of education (Pearson Chi-square=9.63, $\mathrm{df}=7, \mathrm{p}=.21$ ). Caucasian women were significantly more likely to have been stalked by the perpetrator (Pearson Chi-square=4.89, $\mathrm{df}=1, \mathrm{p}=.02$ ). Table 7 provides data used in this analysis.

Table 7. Reports of Whether Victim was Stalked by the Perpetrator

\begin{tabular}{|l|l|r|r|r|}
\hline Race & & $\begin{array}{c}\text { Not } \\
\text { Stalked }\end{array}$ & Stalked & Total \\
\hline African American & $\mathrm{N}$ & 123 & 11 & 134
\end{tabular}




\begin{tabular}{|c|c|c|c|c|}
\hline & $\begin{array}{l}\% \text { within } \\
\text { Race } \\
\mathrm{N}\end{array}$ & $\begin{array}{r}91.8 \% \\
67\end{array}$ & $\begin{array}{r}8.2 \% \\
15\end{array}$ & $\begin{array}{r}100.0 \% \\
82\end{array}$ \\
\hline & $\begin{array}{l}\% \text { within } \\
\text { Race }\end{array}$ & $81.7 \%$ & $18.3 \%$ & $100.0 \%$ \\
\hline \multirow[t]{2}{*}{ Total } & $\mathrm{N}$ & 190 & 26 & 216 \\
\hline & $\begin{array}{l}\% \text { within } \\
\text { Race }\end{array}$ & $88.0 \%$ & $12.0 \%$ & $100.0 \%$ \\
\hline
\end{tabular}

Hypothesis 1B: African American women will be more likely to experience a greater intensity of assault (having a weapon used against them, greater force) than Caucasian women.

Please note that NIJ project officers in a pre-review of a very early draft of this report expressed concern about the ambiguous nature of the term "intensity." A number of items from the interview instrument were used to operationalize this term. These included items pertaining to aspects of the assault (characterizing aspects of the assault such as vaginal penetration, oral sex), whether injuries occurred, and whether a weapon was used during the assault. African American women were not more likely to have sustained physical injuries (Pearson Chi-square=.256, $\mathrm{df}=1$, $\mathrm{p}=.61$ ), nor to have had a weapon used against them (Pearson Chi-square $=1.77, \mathrm{df}=1, \mathrm{p}=.18$ ). In fact, when looking at the specific injuries women sustained, there were no reports of differences, other than that Caucasian women were more likely to sustain internal injuries from their attack (Pearson Chi-square $=4.57, \mathrm{df}=1, \mathrm{p}=.03^{*}$ ). Hence, hypothesis $1 \mathrm{~B}$ was not confirmed. Relevant data are presented in Tables 8 and 9.

Table 8. Reports of Physical Injuries and Weapons Used From/During the Assault

\begin{tabular}{|ll|l|l|l|}
\hline \multirow{2}{*}{ Race } & \multicolumn{2}{|l|}{ Physical injuries } & Total \\
\cline { 3 - 5 } & & No & Yes & \\
\hline African American & $\mathrm{N}$ & 67 & 70 & 137 \\
& $\%$ within Race & $48.9 \%$ & $51.1 \%$ & $100.0 \%$ \\
\multirow{2}{*}{ Caucasian } & $\mathrm{N}$ & 43 & 39 & 82 \\
Total & $\%$ within Race & $52.4 \%$ & $47.6 \%$ & $100.0 \%$ \\
& $\mathrm{~N}$ & 110 & 109 & 219 \\
& $\%$ within Total & $50.2 \%$ & $49.8 \%$ & $100.0 \%$ \\
\hline & & \multicolumn{2}{|c|}{ Weapon used } & Total \\
\hline
\end{tabular}




\begin{tabular}{|ll|r|r|r|}
\cline { 3 - 4 } & & \multicolumn{1}{|c|}{ No } & \multicolumn{1}{c|}{ Yes } & \\
\hline African American & $\mathrm{N}$ & 89 & 49 & 138 \\
& $\%$ within Race & $64.5 \%$ & $35.5 \%$ & $100.0 \%$ \\
Caucasian & $\mathrm{N}$ & 60 & 22 & 82 \\
Total & $\%$ within Race & $73.2 \%$ & $26.8 \%$ & $100.0 \%$ \\
& $\mathrm{~N}$ & 149 & 71 & 220 \\
& $\%$ within Total & $67.7 \%$ & $32.3 \%$ & $100.0 \%$ \\
\hline
\end{tabular}

Table 9. Reports of Internal Injuries from the Assault.

\begin{tabular}{|l|l|r|r|r|}
\hline Race & & $\begin{array}{c}\text { No internal } \\
\text { injuries }\end{array}$ & $\begin{array}{c}\text { Internal } \\
\text { injuries }\end{array}$ & \multicolumn{1}{c|}{ Total } \\
\hline African American & $\mathrm{N}$ & 65 & 6 & 71 \\
& $\%$ within & $91.5 \%$ & $8.5 \%$ & $100.0 \%$ \\
Caucasian & Race & 30 & 9 & 39 \\
Total & \% within & $76.9 \%$ & $23.1 \%$ & $100.0 \%$ \\
& Race & 95 & 15 & 110 \\
& $\mathrm{~N}$ & $86.4 \%$ & $13.6 \%$ & $100.0 \%$ \\
\hline
\end{tabular}

Hypothesis 2A1: Fewer African American women will indicate that they reported their sexual assault to police than Caucasian women.

There was no difference in reporting the assault to the police based on race (Pearson Chisquare $=.645, \mathrm{df}=1, \mathrm{p}=.42$ ) as amplified in Table 10 .

Table 10. Reports of Telling the Police About the Assault

\begin{tabular}{|c|c|c|c|c|}
\hline Race & & $\begin{array}{c}\text { Did not tell } \\
\text { police about } \\
\text { sexual assault }\end{array}$ & $\begin{array}{c}\text { Told police } \\
\text { about } \\
\text { sexual } \\
\text { assault }\end{array}$ & Total \\
\hline \multirow[t]{2}{*}{ African American } & $\bar{N}$ & 85 & 53 & 138 \\
\hline & $\%$ within Race & $61.6 \%$ & $38.4 \%$ & $100.0 \%$ \\
\hline \multirow[t]{2}{*}{ Caucasian } & $N$ & 46 & 36 & 82 \\
\hline & $\%$ within Race & $56.1 \%$ & $43.9 \%$ & $100.0 \%$ \\
\hline \multirow[t]{2}{*}{ Total } & $\mathrm{N}$ & 131 & 89 & 220 \\
\hline & $\%$ within Total & $59.5 \%$ & $40.5 \%$ & $100.0 \%$ \\
\hline
\end{tabular}


The large majority of women did not plan to file criminal charges, regardless of race

(Pearson Chi-square=1.39, $\mathrm{df}=1, \mathrm{p}=.24$ ), as further presented in Table 11 .

\section{Table 11. Reports of Plans to File Criminal Charges}

\begin{tabular}{|c|c|c|c|c|}
\hline \multirow[b]{2}{*}{ Race } & & \multicolumn{2}{|c|}{$\begin{array}{c}\text { Plan to file criminal } \\
\text { charges }\end{array}$} & \multirow[t]{2}{*}{ Total } \\
\hline & & No & Yes & \\
\hline \multirow[t]{2}{*}{ African American } & $\mathrm{N}$ & 70 & 4 & 74 \\
\hline & $\%$ within Race & $94.6 \%$ & $5.4 \%$ & $100.0 \%$ \\
\hline \multirow[t]{2}{*}{ Caucasian } & $\mathrm{N}$ & 39 & 5 & 44 \\
\hline & $\%$ within Race & $88.6 \%$ & $11.4 \%$ & $100.0 \%$ \\
\hline \multirow[t]{2}{*}{ Total } & $\mathrm{N}$ & 109 & 9 & 118 \\
\hline & $\%$ within Total & $92.4 \%$ & $7.6 \%$ & $100.0 \%$ \\
\hline
\end{tabular}

In further exploring other factors that led to police reports, we discovered that African American women with a high level of income were less likely to tell the police than Caucasian women of high income (Pearson Chi-square $=4.58, \mathrm{df}=1, \mathrm{p}=.032 *$ ). Thus, there was only partial support for Hypothesis 2A1, with income as a potential mediating variable.

Hypothesis 2A2: African American women will indicate a number of racial and cultural barriers in reporting sexual assault to police.

As reviewed in Appendix D, here a number of variables were used to explore this hypothesis. First, the race of the perpetrator of the sexual assault differed significantly depending on the race of the victim. Victims were much more likely to be assaulted by someone of their own race (Pearson Chi-square $=109.88, \mathrm{df}=6, \mathrm{p}=.000^{* *}$ ) as further presented in Table 12 . Table 12. Reports of Race of Perpetrators

\begin{tabular}{|c|c|c|c|c|c|c|c|c|}
\hline \multirow[b]{2}{*}{ Race of survivor } & \multicolumn{7}{|c|}{ Race/Ethnicity of perpetrator } & \multirow[t]{2}{*}{ Total } \\
\hline & White & $\begin{array}{c}\text { African } \\
\text { American }\end{array}$ & $\begin{array}{l}\text { Asian/ } \\
\text { Pacific } \\
\text { Islander }\end{array}$ & $\begin{array}{l}\text { American } \\
\text { Indian/ } \\
\text { Alaska } \\
\text { Native }\end{array}$ & Hispanic & Other & Unknown & \\
\hline African & $\overline{6}$ & 123 & 1 & 0 & 1 & 5 & 3 & 139 \\
\hline
\end{tabular}




\begin{tabular}{|c|c|c|c|c|c|c|c|c|c|}
\hline American & $\begin{array}{l}\% \text { within } \\
\text { Race }\end{array}$ & $4.3 \%$ & $88.5 \%$ & $.7 \%$ & $.0 \%$ & $.7 \%$ & $3.6 \%$ & $2.2 \%$ & $100.0 \%$ \\
\hline \multirow[b]{2}{*}{ Caucasian } & N & 52 & 21 & 2 & 1 & 5 & 2 & 0 & 83 \\
\hline & $\begin{array}{l}\% \text { within } \\
\text { Race }\end{array}$ & $\begin{array}{r}62.7 \\
\%\end{array}$ & $25.3 \%$ & $2.4 \%$ & $1.2 \%$ & $6.0 \%$ & $2.4 \%$ & $.0 \%$ & $100.0 \%$ \\
\hline \multirow[t]{2}{*}{ Total } & $\mathrm{N}$ & 58 & 144 & 3 & 1 & 6 & 7 & 3 & 222 \\
\hline & $\begin{array}{l}\% \text { within } \\
\text { Total }\end{array}$ & $\begin{array}{r}26.1 \\
\%\end{array}$ & $64.9 \%$ & $1.4 \%$ & $.5 \%$ & $2.7 \%$ & $3.2 \%$ & $1.4 \%$ & $100.0 \%$ \\
\hline
\end{tabular}

As presented earlier, African American women only at high income levels were less likely to report their assaults to the police. We conducted qualitative analyses to further explore this finding and potential barriers to reporting. These analyses followed the approach used for analyses of focus group data presented on page 25. In addition, themes for the interview openended questions were rank ordered and percentages were calculated. Below are the major themes relevant to Hypothesis 2A2, followed by one or two representative quotes. African American women with high levels of income $(\$ 50,000$ or more per year $)(n=14)$ reported that they did not report their assault because they were young or naive:

“I was young. Basically I didn't know what to do."

"I was a child."

“Cause I didn't think it was rape.”

“Didn't realize that is was unnormal and didn't want the person to get into trouble" Some African American women with high income levels didn’t go to the police because of issues of confidentiality or just wanting to move on:

"I couldn't describe him what was I going to tell them that was going to help. I was living in a shelter and didn't want everyone else to know. I am a private person and they were total strangers."

“Because I didn't want them to get into my personal sexual history and my life and my perception of treatment of women in these kinds of situations is negative and I didn't want to go through that."

"I wanted to put it behind me." 
Lastly, some African American women with high levels of income reported being afraid to go to the police for a variety of reasons:

"I was scared. I actually thought it was kind of my fault 'cause I shouldn't have gone with him to his house."

"Because of warrant for arrest out for me."

Another dimension of barriers to reporting was satisfaction with police encounters. Many women reported feeling dissatisfied with their interactions with the police, but there were not differences in satisfaction based on the victim's race. There were no significant differences in how African American and Caucasian women rated their satisfaction with the police interview (Pearson Chi-square=1.83, $\mathrm{df}=3, \mathrm{p}=.61$ ), with how police handled their case (Pearson Chisquare $=4.03, \mathrm{df}=3, \mathrm{p}=.25$ ) or with how satisfied they were with their overall interactions with police (Pearson Chi-square=3.20, $\mathrm{df}=3, \mathrm{p}=.36$ ), as further presented in Table 13 .

\section{Table 13. Reports of Satisfaction with Interactions with the Police}

\begin{tabular}{|c|c|c|c|c|c|c|}
\hline \multirow[b]{2}{*}{ Race } & & \multicolumn{4}{|c|}{ Satisfaction with police interview } & \multirow[b]{2}{*}{ Total } \\
\hline & & dissatisfied & Dissatisfied & Satisfied & Very satisfied & \\
\hline \multirow[t]{2}{*}{ African American } & $\mathrm{N}$ & 12 & 5 & 16 & 15 & 48 \\
\hline & $\begin{array}{l}\% \text { within } \\
\text { Race }\end{array}$ & $25.0 \%$ & $10.4 \%$ & $33.3 \%$ & $31.3 \%$ & $100.0 \%$ \\
\hline \multirow[t]{2}{*}{ Caucasian } & $\mathrm{N}$ & 10 & 4 & 6 & 8 & 28 \\
\hline & $\begin{array}{l}\% \text { within } \\
\text { Race }\end{array}$ & $35.7 \%$ & $14.3 \%$ & $21.4 \%$ & $28.6 \%$ & $100.0 \%$ \\
\hline \multirow[t]{2}{*}{ Total } & $\mathrm{N}$ & 22 & 9 & 22 & 23 & 76 \\
\hline & $\%$ within Total & $28.9 \%$ & $11.8 \%$ & $28.9 \%$ & $30.3 \%$ & $100.0 \%$ \\
\hline \multirow[b]{2}{*}{ Race } & & \multicolumn{4}{|c|}{ Satisfaction with how police handled case } & \\
\hline & & $\begin{array}{c}\text { Very } \\
\text { dissatisfied }\end{array}$ & Dissatisfied & Satisfied & Very satisfied & Total \\
\hline \multirow[t]{2}{*}{ African American } & $\mathrm{N}$ & 11 & 7 & 15 & 17 & 50 \\
\hline & $\begin{array}{l}\text { \% within } \\
\text { Race }\end{array}$ & $22.0 \%$ & $14.0 \%$ & $30.0 \%$ & $34.0 \%$ & $100.0 \%$ \\
\hline \multirow[t]{2}{*}{ Caucasian } & $N$ & 12 & 2 & 6 & 8 & 28 \\
\hline & $\begin{array}{l}\% \text { within } \\
\text { Race }\end{array}$ & $42.9 \%$ & $7.1 \%$ & $21.4 \%$ & $28.6 \%$ & $100.0 \%$ \\
\hline \multirow[t]{2}{*}{ Total } & $\mathrm{N}$ & 23 & 9 & 21 & 25 & 78 \\
\hline & $\%$ within Total & $29.5 \%$ & $11.5 \%$ & $26.9 \%$ & $32.1 \%$ & $100.0 \%$ \\
\hline
\end{tabular}




\begin{tabular}{|c|c|c|c|c|c|c|}
\hline \multirow[b]{2}{*}{ Race } & & \multicolumn{4}{|c|}{ Satisfaction with overall interactions with police } & \multirow[b]{2}{*}{ Total } \\
\hline & & $\begin{array}{c}\text { Very } \\
\text { dissatisfied }\end{array}$ & Dissatisfied & Satisfied & Very satisfied & \\
\hline \multirow[t]{2}{*}{ African American } & Count & 10 & 7 & 18 & 14 & 49 \\
\hline & $\begin{array}{l}\% \text { within } \\
\text { Race }\end{array}$ & $20.4 \%$ & $14.3 \%$ & $36.7 \%$ & $28.6 \%$ & $100.0 \%$ \\
\hline \multirow[t]{2}{*}{ Caucasian } & Count & 10 & 2 & 7 & 7 & 26 \\
\hline & $\begin{array}{l}\text { \% within } \\
\text { Race }\end{array}$ & $38.5 \%$ & $7.7 \%$ & $26.9 \%$ & $26.9 \%$ & $100.0 \%$ \\
\hline \multirow[t]{2}{*}{ Total } & Count & 20 & 9 & 25 & 21 & 75 \\
\hline & $\begin{array}{l}\% \text { within } \\
\text { Race }\end{array}$ & $26.7 \%$ & $12.0 \%$ & $33.3 \%$ & $28.0 \%$ & $100.0 \%$ \\
\hline
\end{tabular}

Another dimension to barriers to reporting was perceptions of whether the police believed them. The majority of women felt that the police believed them, and race was not a significant factor in whether or not they felt believed (Pearson Chi-square=1.22, $\mathrm{df}=1, \mathrm{p}=.27$ ), as further presented in Table 14.

Table 14. Reports of Whether Police Believed Survivor Statements

\begin{tabular}{|c|c|c|c|c|}
\hline Race & & $\begin{array}{c}\text { Think } \\
\text { police did } \\
\text { not believe }\end{array}$ & $\begin{array}{c}\text { Think } \\
\text { police } \\
\text { believed }\end{array}$ & Total \\
\hline \multirow[t]{2}{*}{ African American } & Count & 12 & 36 & 48 \\
\hline & $\begin{array}{l}\% \text { within } \\
\text { Race }\end{array}$ & $25.0 \%$ & $75.0 \%$ & $100.0 \%$ \\
\hline \multirow[t]{2}{*}{ Caucasian } & Count & 4 & 24 & 28 \\
\hline & $\begin{array}{l}\% \text { within } \\
\text { Race }\end{array}$ & $14.3 \%$ & $85.7 \%$ & $100.0 \%$ \\
\hline \multirow[t]{2}{*}{ Total } & Count & 16 & 60 & 76 \\
\hline & $\begin{array}{l}\% \text { within } \\
\text { Race }\end{array}$ & $21.1 \%$ & $78.9 \%$ & $100.0 \%$ \\
\hline
\end{tabular}

To further explore the issues around whether or not the victims felt believed by the police, we conducted a qualitative analysis of the responses to the interview question, "What made you think the police did or did not believe you?” Table 15 provides a breakdown of responses to this question.

\section{Table 15. Reasons Participants Felt Police Did or Did Not Believe Them}




\begin{tabular}{|c|c|c|c|}
\hline $\begin{array}{l}\text { African } \\
\text { American } \\
\text { (n) }\end{array}$ & $\begin{array}{c}\text { Caucasian } \\
\text { (n) }\end{array}$ & Total & Themes-Police did believe \\
\hline 5 & 8 & 14 & Physical evidence of assault \\
\hline 10 & 5 & 15 & Expressed kindness or other nonverbal cues \\
\hline 8 & 6 & 14 & Prompt response \\
\hline 23 & 19 & 42 & \\
\hline $\begin{array}{l}\text { African } \\
\text { American } \\
\text { (n) }\end{array}$ & $\begin{array}{c}\text { Caucasian } \\
\text { (n) }\end{array}$ & Total & Themes-Police did not believe \\
\hline 5 & 4 & 9 & Attitudes and actions of police \\
\hline 4 & 2 & 6 & Poor treatment \\
\hline 9 & 6 & 17 & \\
\hline
\end{tabular}

Statements amplifying perceptions of belief by the police are presented in the following

$(\mathrm{AA}=$ African American and $\mathrm{C}=$ Caucasian $)$ :

"Because they could feel the pain. It was there. You would have to be a manikin not to see the pain.” (AA)

"Their attitude - they listened to my story. Showed empathy.” (AA)

"They could see that I had been assaulted, beaten, and raped." (C)

“They acted very quickly because my uncle had a little girl at home.” (C)

Statements amplifying perceptions of disbelief (or poor response) by the police are

presented in the following:

"Female - sat down with me to talk to me and asked for a description; male - looked at me as if I was lying because I didn't show no reaction as a person who just got raped." (AA)

"Some of the police knew him from football - laughed and kept talking with him. They believed all his lies." (AA)

"At first they seemed to - after they went to his house they changed attitude. They believed his story that I had consented." (C)

"Just like I told you before. Due to drugs and alcohol he didn't file a report but I think he believed me.” (C) 
Thus, there is partial support for Hypothesis 2A2. While African American women did report a number of barriers to reporting sexual assault to police, there were no clear racial differences in data used to explore this hypothesis.

Hypothesis 2B1: Fewer African American women will indicate that they sought medical and psychological services following sexual assault than Caucasian women.

As presented in Appendix D, many items from the interview instrument were used to explore this hypothesis. These items fall in major categories of Medical Treatment, Sexual Assault Crisis Center Services, and Other Counseling Services. Findings in these categories are presented in the following.

\section{$\underline{\text { Medical Treatment }}$}

There were no significant differences in medical treatment for African American versus Caucasian women (Pearson Chi-square=3.20, $\mathrm{df}=1, \mathrm{p}=.07$ ), as further presented in Table 16 .

\section{Table 16. Reports of Medical Treatment Sought and Received}

\begin{tabular}{|l|l|r|r|r|}
\hline & & $\begin{array}{c}\text { Did not } \\
\text { seek } \\
\text { medical } \\
\text { care }\end{array}$ & $\begin{array}{c}\text { Sought } \\
\text { medical } \\
\text { care }\end{array}$ & \multicolumn{1}{c|}{ Total } \\
\hline African American & $\mathrm{N}$ & 75 & 63 & 138 \\
Caucasian & $\%$ within Race & $54.3 \%$ & $45.7 \%$ & $100.0 \%$ \\
Total & $\mathrm{N}$ & 54 & 27 & 81 \\
& $\%$ within Race & $66.7 \%$ & $33.3 \%$ & $100.0 \%$ \\
& $\mathrm{~N}$ & 129 & 90 & 219 \\
& $\%$ within Total & $58.9 \%$ & $41.1 \%$ & $100.0 \%$ \\
\hline
\end{tabular}

Post-hoc analyses indicate that Caucasian women with low levels of education were significantly less likely than African American women with low education to seek medical care (73.5\% versus 48.4\%, (Pearson Chi-square=8.21, $\left.\mathrm{df}=1, \mathrm{p}=.004^{* *}\right)$.

\section{$\underline{\text { Sexual Assault Crisis Center }}$}


African American women were significantly less likely to receive services from a sexual assault crisis center (SACC; Pearson Chi-square $=4.62, \mathrm{df}=1, \mathrm{p}=.032^{*}$ ) as further presented in Table 17.

Table 17. Reports of Services Received from Sexual Assault Crisis Centers

\begin{tabular}{|ll|r|r|r|}
\hline Race & $\begin{array}{c}\text { Did not } \\
\text { receive } \\
\text { services }\end{array}$ & $\begin{array}{c}\text { Received } \\
\text { services }\end{array}$ & \multicolumn{1}{|c|}{ Total } \\
\hline African American & $\mathrm{N}$ & 109 & 29 & 138 \\
Caucasian & $\%$ within Race & $79.0 \%$ & $21.0 \%$ & $100.0 \%$ \\
& $\mathrm{~N}$ & 54 & 28 & 82 \\
Total & $\%$ within Race & $65.9 \%$ & $34.1 \%$ & $100.0 \%$ \\
& $\mathrm{~N}$ & 163 & 57 & 220 \\
& $\%$ within Race & $74.1 \%$ & $25.9 \%$ & $100.0 \%$ \\
\hline
\end{tabular}

There were no significant differences based on race in the types of services the women received from the SACCs. Eighty-two percent of the women who received services from a SACC received individual counseling, 29\% participated in group counseling, 50\% called a SACC hotline, $20 \%$ received legal services and $21 \%$ obtained advocacy services.

\section{Other counseling services}

African American women were also less likely to receive counseling services from sources other than a SACC (Pearson Chi-square $=6.69, \mathrm{df}=1, \mathrm{p}=.010^{* *}$ ) as further presented in Table 18.

Table 18. Reports of Counseling Services Received in Other Sites

\begin{tabular}{|l|l|r|r|r|}
\hline & & $\begin{array}{c}\text { Did not } \\
\text { receive } \\
\text { services }\end{array}$ & $\begin{array}{c}\text { Received } \\
\text { counseling } \\
\text { services }\end{array}$ & \multicolumn{1}{c|}{ Total } \\
\hline Race & $\mathrm{N}$ & 89 & 47 & 136 \\
Caucan American & $\%$ within Race & $65.4 \%$ & $34.6 \%$ & $100.0 \%$ \\
& $\mathrm{~N}$ & 38 & 42 & 80 \\
Total & $\%$ within Race & $47.5 \%$ & $52.5 \%$ & $100.0 \%$ \\
& $\mathrm{~N}$ & 127 & 89 & 216
\end{tabular}


African American women were also much less likely to obtain services from a therapist or counselor (Pearson Chi-square=5.11, $\mathrm{df}=1, \mathrm{p}=.024^{*}$ ) as further presented in Table 19.

Table 19. Reports of Obtaining Services from a Therapist or Counselor

\begin{tabular}{|ll|r|r|r|}
\hline Race & $\begin{array}{c}\text { Did not } \\
\text { receive } \\
\text { counseling }\end{array}$ & $\begin{array}{c}\text { Received } \\
\text { counseling }\end{array}$ & Total \\
\hline African American & $\mathrm{N}$ & 19 & 27 & 46 \\
& $\%$ within Race & $41.3 \%$ & $58.7 \%$ & $100.0 \%$ \\
Caucasian & $\mathrm{N}$ & 8 & 34 & 42 \\
Total & \% within Race & $19.0 \%$ & $81.0 \%$ & $100.0 \%$ \\
& $\mathrm{~N}$ & 27 & 61 & 88 \\
& \% within Total & $30.7 \%$ & $69.3 \%$ & $100.0 \%$ \\
\hline
\end{tabular}

In contrast, African American women who obtained counseling services outside of a SACC were nearly twice as likely to have that source be something other than a therapist, hospital or pastor (Pearson Chi-square=3.998, $\mathrm{df}=1, \mathrm{p}=.046^{*}$ ), as further presented in Table 20. Table 20. Reports of Counseling from Non-Traditional Sources

\begin{tabular}{|ll|r|r|r|}
\hline Race & $\begin{array}{c}\text { Did not } \\
\text { receive } \\
\text { counseling }\end{array}$ & $\begin{array}{c}\text { Received } \\
\text { counseling }\end{array}$ & Total \\
\hline African American & $\mathrm{N}$ & 27 & 19 & 46 \\
Caucasian & $\%$ within Race & $58.7 \%$ & $41.3 \%$ & $100.0 \%$ \\
& $\mathrm{~N}$ & 33 & 9 & 42 \\
Total & $\%$ within Race & $78.6 \%$ & $21.4 \%$ & $100.0 \%$ \\
& $\mathrm{~N}$ & 60 & 28 & 88 \\
& $\%$ within Total & $68.2 \%$ & $31.8 \%$ & $100.0 \%$ \\
\hline
\end{tabular}

Most women did not receive counseling services from a hospital, and there were no differences based on race (Pearson Chi-square=.369, $\mathrm{df}=1, \mathrm{p}=.544$ ), as shown in Table 21 . Table 21. Reports of Counseling Services Received in the Hospital

\begin{tabular}{|l|c|c|c|}
\hline Race & $\begin{array}{c}\text { Did not } \\
\text { receive } \\
\text { counseling } \\
\text { from }\end{array}$ & $\begin{array}{c}\text { Received } \\
\text { counseling } \\
\text { from } \\
\text { hospital }\end{array}$ & Total \\
\hline
\end{tabular}




\begin{tabular}{|ll|r|r|r|}
\hline & & hospital & & \\
\hline African American & $\mathrm{N}$ & 41 & 5 & 46 \\
& $\%$ within Race & $89.1 \%$ & $10.9 \%$ & $100.0 \%$ \\
Caucasian & $\mathrm{N}$ & 39 & 3 & 42 \\
& $\%$ within Race & $92.9 \%$ & $7.1 \%$ & $100.0 \%$ \\
Total & $\mathrm{N}$ & 80 & 8 & 88 \\
& $\%$ within Total & $90.9 \%$ & $9.1 \%$ & $100.0 \%$ \\
\hline
\end{tabular}

Thus, support for hypothesis 2B1 was mixed. There were no overall differences in medical treatment following assault for African American versus Caucasian women. However, among women of lower income, Caucasian women were less likely to receive this treatment. African American women were less likely to receive services at sexual assault crisis centers (SACCs), however there were no differences in types of services received for the women who received them. African American women were less likely to receive counseling services from sites other than SACCs and were less like to receive services from therapists or counselors, and more likely to receive counseling from nontraditional sources than Caucasian women.

Hypothesis 2B2: African American women will report a number of racial and cultural barriers in seeking and receiving medical and psychological services following sexual assault.

As presented in Appendix D, this is a complicated hypothesis with many interview items further exploring it in dimensions of Tested for Sexually Transmitted Diseases (STDs), Satisfaction with Medical Services, Reasons for not Obtaining Services from a SACC, Satisfaction with SACC Services, Latency from Assault to SACC Services, What Prevented Coming to SACC Sooner, and Latency from Assault to Counseling Services. Findings in these categories are presented in the following.

Tested for Sexually Transmitted Diseases

There was no significant difference in the rates of sexually transmitted disease testing for African American versus Caucasian women, but there was a trend for African American women 
to be more likely to get tested for sexually transmitted diseases (Pearson Chi-square=3.483, $\mathrm{df}=1, \mathrm{p}=.062$ ), as further presented in Table 22 .

Table 22. Reports of Receiving Testing for STDs

\begin{tabular}{|c|c|c|c|c|}
\hline Race & & $\begin{array}{l}\text { Not tested } \\
\text { for STD }\end{array}$ & $\begin{array}{l}\text { Tested for } \\
\text { STD }\end{array}$ & Total \\
\hline \multirow[t]{2}{*}{ African American } & $\mathrm{N}$ & 10 & 48 & 58 \\
\hline & $\begin{array}{l}\text { \% within } \\
\text { Race }\end{array}$ & $17.2 \%$ & $82.8 \%$ & $100.0 \%$ \\
\hline \multirow[t]{2}{*}{ Caucasian } & $\mathrm{N}$ & 9 & 16 & 25 \\
\hline & $\begin{array}{l}\text { \% within } \\
\text { Race }\end{array}$ & $36.0 \%$ & $64.0 \%$ & $100.0 \%$ \\
\hline \multirow[t]{2}{*}{ Total } & $\mathrm{N}$ & 19 & 64 & 83 \\
\hline & $\%$ within Total & $22.9 \%$ & $77.1 \%$ & $100.0 \%$ \\
\hline
\end{tabular}

\section{$\underline{\text { Satisfaction with Medical Services }}$}

There were no differences in satisfaction with physical examination (Pearson Chisquare=1.448, $\mathrm{df}=3, \mathrm{p}=.694$ ), satisfaction with testing for STDs (Pearson Chi-square=2.571, $\mathrm{df}=3, \mathrm{p}=.463$ ), or satisfaction with the information they received about emergency contraception (Pearson Chi-square=.421, $\mathrm{df}=3, \mathrm{p}=.936$ ), as shown in Table 23.

\section{Table 23. Reports of Satisfaction with Medical Services}

\begin{tabular}{|c|c|c|c|c|c|c|}
\hline \multicolumn{2}{|l|}{ Race } & \multicolumn{4}{|c|}{ Satisfaction with physical examination } & \multirow[t]{2}{*}{ Total } \\
\hline & & $\begin{array}{c}\text { Very } \\
\text { dissatisfied }\end{array}$ & Dissatisfied & Satisfied & $\begin{array}{c}\text { Very } \\
\text { satisfied }\end{array}$ & \\
\hline \multirow[t]{2}{*}{ African American } & $\mathrm{N}$ & 6 & 10 & 14 & 30 & 60 \\
\hline & $\%$ within Race & $10.0 \%$ & $16.7 \%$ & $23.3 \%$ & $50.0 \%$ & $100.0 \%$ \\
\hline \multirow[t]{2}{*}{ Caucasian } & $\mathrm{N}$ & 2 & 5 & 8 & 9 & 24 \\
\hline & $\%$ within Race & $8.3 \%$ & $20.8 \%$ & $33.3 \%$ & $37.5 \%$ & $100.0 \%$ \\
\hline \multirow[t]{3}{*}{ Total } & $\mathrm{N}$ & 8 & 15 & 22 & 39 & 84 \\
\hline & $\%$ within Total & $9.5 \%$ & $17.9 \%$ & $26.2 \%$ & $46.4 \%$ & $100.0 \%$ \\
\hline & & \multicolumn{4}{|c|}{ Satisfaction with testing for STDs } & Total \\
\hline \multirow[t]{2}{*}{ African American } & $\mathrm{N}$ & 4 & 5 & 11 & 31 & 51 \\
\hline & $\%$ within Race & $7.8 \%$ & $9.8 \%$ & $21.6 \%$ & $60.8 \%$ & $100.0 \%$ \\
\hline \multirow[t]{2}{*}{ Caucasian } & $\mathrm{N}$ & 1 & 3 & 6 & 7 & 17 \\
\hline & $\%$ within Race & $5.9 \%$ & $17.6 \%$ & $35.3 \%$ & $41.2 \%$ & $100.0 \%$ \\
\hline Total & $\mathrm{N}$ & 5 & 8 & 17 & 38 & 68 \\
\hline
\end{tabular}


This document is a research report submitted to the U.S. Department of Justice. This report has not been published by the Department. Opinions or points of view expressed are those of the author(s) and do not necessarily reflect the official position or policies of the U.S. Department of Justice.

\begin{tabular}{|ll|r|r|r|r|r|} 
& \% within Total & $7.4 \%$ & $11.8 \%$ & $25.0 \%$ & $55.9 \%$ & $100.0 \%$ \\
\hline & & \multicolumn{2}{c}{ Satisfaction with info about emergency contraception } & Total \\
\hline African American & $\mathrm{N}$ & 12 & 4 & 10 & 15 & 41 \\
& $\%$ within Race & $29.3 \%$ & $9.8 \%$ & $24.4 \%$ & $36.6 \%$ & $100.0 \%$ \\
Caucasian & $\mathrm{N}$ & 3 & 1 & 3 & 6 & 13 \\
& $\%$ within Race & $23.1 \%$ & $7.7 \%$ & $23.1 \%$ & $46.2 \%$ & $100.0 \%$ \\
Total & $\mathrm{N}$ & 15 & 5 & 13 & 21 & 54 \\
& $\%$ within Total & $27.8 \%$ & $9.3 \%$ & $24.1 \%$ & $38.9 \%$ & $100.0 \%$ \\
\hline
\end{tabular}

Reason for not Obtaining Services from a SACC

Some African American women reported that they did not contact a SACC because they didn't know about SACCs:

"Never knew where they were"

"I didn't know about a sexual assault crisis center. All I wanted to do was get through my injuries and smoke some crack."

Some African American women reported that they were too young at the time of the rape to seek services on their own:

“I don't think they existed. I wasn't old enough to go out of my home to seek help. And again, you just don't want to tell people. You don't want to tell more than you have to."

"Scared. Young. How could I go by myself?"

Some African American women did not seek services because they were in denial about the assault:

"I just blocked everything out - went on with my life as if it never happened."

Some African American women did not seek services because they did not want to reveal the assault:

“Because I didn't tell anyone and because I knew nothing about those types of services. Besides, even if I did I would not have told because he told me what he would do to my mother if I told."

Some African American women did not feel that they needed help, so they did not seek services: 
"'Cause I didn't think I really needed it. Thought it was for someone who really couldn't cope. I'm strong as far as that is concerned. Good at handling things."

Finally, some African American women did not seek services because they preferred to rely on family support:

"I wouldn't feel right talking to a stranger about my problems. My family is my counseling."

"I didn't go through all the counseling and stuff. I didn't tell authorities. I told my mother, brother, and sister."

\section{$\underline{\text { Satisfaction with SACC Services }}$}

The women who received services from a SACC were very satisfied with those services, regardless of race (Pearson Chi-square=7.149, $\mathrm{df}=4, \mathrm{p}=.128$ ), as further presented in Table 24 .

\section{Table 24. Ratings of Satisfaction with SACC Services}

\begin{tabular}{|ll|r|r|r|r|r|r|}
\hline \multirow{2}{*}{ Race } & \multicolumn{6}{|c|}{ Rate overall services at SACC } & \multicolumn{2}{c|}{ Total } \\
\cline { 2 - 8 } & & Very poor & Poor & Adequate & Good & \multicolumn{1}{c|}{ gory } & \\
\hline African American & $\mathrm{N}$ & 1 & 1 & 0 & 10 & 16 & 28 \\
& $\%$ within Race & $3.6 \%$ & $3.6 \%$ & $.0 \%$ & $35.7 \%$ & $57.1 \%$ & $100.0 \%$ \\
Caucasian & $\mathrm{N}$ & 0 & 1 & 2 & 3 & 20 & 26 \\
& $\%$ within Race & $.0 \%$ & $3.8 \%$ & $7.7 \%$ & $11.5 \%$ & $76.9 \%$ & $100.0 \%$ \\
Total & $\mathrm{N}$ & 1 & 2 & 2 & 13 & 36 & 54 \\
& $\%$ within Total & $1.9 \%$ & $3.7 \%$ & $3.7 \%$ & $24.1 \%$ & $66.7 \%$ & $100.0 \%$ \\
\hline
\end{tabular}

Women who received individual counseling were very satisfied with those services, and there were no differences based on race (Pearson Chi-square $=2.0, \mathrm{df}=3, \mathrm{p}=.571$ ), as shown in Table 25.

Table 25. Ratings of Satisfaction with Individual Counseling in SACCs

\begin{tabular}{|ll|r|r|r|r|r|}
\hline \multirow{2}{*}{ Race } & \multicolumn{4}{|c|}{ Satisfaction with individual counseling } & Total \\
\cline { 3 - 7 } & \multicolumn{2}{|c|}{$\begin{array}{c}\text { Very } \\
\text { dissatisfied }\end{array}$} & Dissatisfied & Satisfied & $\begin{array}{c}\text { Very } \\
\text { satisfied }\end{array}$ \\
\hline African & $\mathrm{N}$ & 0 & 1 & 3 & 19 & 23 \\
American & $\%$ within Race & $.0 \%$ & $4.3 \%$ & $13.0 \%$ & $82.6 \%$ & $100.0 \%$ \\
Caucasian & $\mathrm{N}$ & 1 & 0 & 3 & 18 & 22 \\
& $\%$ within Race & $4.5 \%$ & $.0 \%$ & $13.6 \%$ & $81.8 \%$ & $100.0 \%$ \\
Total & $\mathrm{N}$ & 1 & 1 & 6 & 37 & 45
\end{tabular}


Caucasian women reported higher levels of satisfaction with the SACC hotline than African American women did (Pearson Chi-square=9.075, $\mathrm{df}=3, \mathrm{p}=.028 *$ ), as further presented in Table 26.

Table 26. Ratings of Satisfaction with the SACC Hotline

\begin{tabular}{|ll|r|r|r|r|r|}
\hline \multirow{2}{*}{ Race } & \multicolumn{4}{|c|}{ Satisfaction with sexual assault hotline } & Total \\
\cline { 3 - 7 } & & \multicolumn{2}{|c|}{$\begin{array}{c}\text { Very } \\
\text { dissatisfied }\end{array}$} & Dissatisfied & Satisfied & \multicolumn{2}{c|}{$\begin{array}{l}\text { Very } \\
\text { satisfied }\end{array}$} \\
\hline African & $\mathrm{N}$ & 2 & 0 & 7 & 4 & 13 \\
American & $\%$ within Race & $15.4 \%$ & $.0 \%$ & $53.8 \%$ & $30.8 \%$ & $100.0 \%$ \\
Caucasian & $\mathrm{N}$ & 1 & 1 & 1 & 11 & 14 \\
& $\%$ within Race & $7.1 \%$ & $7.1 \%$ & $7.1 \%$ & $78.6 \%$ & $100.0 \%$ \\
Total & $\mathrm{N}$ & 3 & 1 & 8 & 15 & 27 \\
& \% within Total & $11.1 \%$ & $3.7 \%$ & $29.6 \%$ & $55.6 \%$ & $100.0 \%$ \\
\hline
\end{tabular}

Too few women received group counseling, legal services, or advocacy services from a SACC to evaluate racial differences.

\section{$\underline{\text { Latency from Assault to SACC Services }}$}

It took about half of the assault victims more than a year to come to SACCs for support or services, and there was no difference based on race (Pearson Chi-square=6.40, $\mathrm{df}=5, \mathrm{p}=.27$ ), as further presented in Table 27.

Table 27. Latency from Assault to SACC Services

\begin{tabular}{|c|c|c|c|c|c|c|c|c|}
\hline Race & & $\begin{array}{c}\text { Within } 24 \\
\text { hours of } \\
\text { incident }\end{array}$ & $\begin{array}{c}\text { Within } 1 \\
\text { week }\end{array}$ & $\begin{array}{c}\text { Within } 1 \\
\text { month }\end{array}$ & $\begin{array}{c}\text { Within 2- } \\
6 \\
\text { months }\end{array}$ & $\begin{array}{c}\text { Within 6- } \\
12 \\
\text { months }\end{array}$ & $\begin{array}{c}\text { More } \\
\text { than } 1 \\
\text { year }\end{array}$ & Total \\
\hline \multirow{2}{*}{$\begin{array}{l}\text { African } \\
\text { American }\end{array}$} & $\mathrm{N}$ & 3 & 3 & 5 & 2 & 0 & 16 & 29 \\
\hline & $\begin{array}{l}\text { \% within } \\
\text { Race }\end{array}$ & $10.3 \%$ & $10.3 \%$ & $17.2 \%$ & $6.9 \%$ & $.0 \%$ & $55.2 \%$ & $100.0 \%$ \\
\hline \multirow[t]{2}{*}{ Caucasian } & $\mathrm{N}$ & 0 & 5 & 3 & 5 & 1 & 14 & 28 \\
\hline & $\begin{array}{l}\text { \% within } \\
\text { Race }\end{array}$ & $.0 \%$ & $17.9 \%$ & $10.7 \%$ & $17.9 \%$ & $3.6 \%$ & $50.0 \%$ & $100.0 \%$ \\
\hline \multirow[t]{2}{*}{ Total } & $\mathrm{N}$ & 3 & 8 & 8 & 7 & 1 & 30 & 57 \\
\hline & $\begin{array}{l}\% \text { within } \\
\text { Total }\end{array}$ & $5.3 \%$ & $14.0 \%$ & $14.0 \%$ & $12.3 \%$ & $1.8 \%$ & $52.6 \%$ & $100.0 \%$ \\
\hline
\end{tabular}

What Prevented Coming to SACC Sooner 
Before coming to the SACC, most women reported that they did not know that they

existed, with no difference depending on the woman's race (Pearson Chi-square $=.132, \mathrm{df}=1$, $\mathrm{p}=.716)$, as further presented in Table 28 .

Table 28. Reports of Knowledge of SACCs Prior to Assault

\begin{tabular}{|l|l|r|r|r|}
\hline & & $\begin{array}{l}\text { Did not } \\
\text { know } \\
\text { about } \\
\text { Race }\end{array}$ & $\begin{array}{r}\text { Knew } \\
\text { about } \\
\text { SACC }\end{array}$ & \\
\hline African American & $\mathrm{N}$ & 23 & 5 & 28 \\
& \% within & $82.1 \%$ & $17.9 \%$ & $100.0 \%$ \\
& Race & 24 & 4 & 28 \\
Caucasian & $\mathrm{N}$ & $85.7 \%$ & $14.3 \%$ & $100.0 \%$ \\
Total & Race & 47 & 9 & 56 \\
& $\mathrm{~N}$ & $83.9 \%$ & $16.1 \%$ & $100.0 \%$ \\
\hline
\end{tabular}

However, few women reported that they had difficulty finding the SACC, and this was true for both African American and Caucasian women (Pearson Chi-square=.220, $\mathrm{df}=1, \mathrm{p}=.639$ ), as further presented in Table 29.

Table 29. Reports of Problems Finding SACCs

\begin{tabular}{|l|l|r|r|r|}
\hline & & $\begin{array}{c}\text { No } \\
\text { problems } \\
\text { finding } \\
\text { SACC }\end{array}$ & $\begin{array}{c}\text { Problems } \\
\text { finding } \\
\text { SACC }\end{array}$ & \\
\hline African American & $\mathrm{N}$ & 26 & 2 & 28 \\
& \% within & $92.9 \%$ & $7.1 \%$ & $100.0 \%$ \\
Race & 25 & 3 & 28 \\
Caucasian & $\mathrm{N}$ & $89.3 \%$ & $10.7 \%$ & $100.0 \%$ \\
Total & Race & 51 & 5 & 56 \\
& $\mathrm{~N}$ & $91.1 \%$ & $8.9 \%$ & $100.0 \%$ \\
\hline
\end{tabular}

\section{$\underline{\text { Latency from Assault to Counseling Services }}$}


Most of the women who received counseling began counseling over a year after the assault, and there was no difference based on race (Pearson Chi-square $=3.992, \mathrm{df}=5, \mathrm{p}=.551$ ), as further presented in Table 30 .

Table 30. Latency from Assault to Counseling Services

\begin{tabular}{|c|c|c|c|c|c|c|c|c|}
\hline Race & & $\begin{array}{c}\text { Within } 24 \\
\text { hours of } \\
\text { incident }\end{array}$ & $\begin{array}{l}\text { Within } 1 \\
\text { week }\end{array}$ & $\begin{array}{l}\text { Within } 1 \\
\text { month }\end{array}$ & $\begin{array}{l}\text { Within 2- } \\
6 \text { months }\end{array}$ & $\begin{array}{l}\text { Within 6- } \\
12 \text { months }\end{array}$ & $\begin{array}{c}\text { More } \\
\text { than } 1 \\
\text { year }\end{array}$ & Total \\
\hline \multirow{2}{*}{$\begin{array}{l}\text { African } \\
\text { American }\end{array}$} & Count & 2 & 4 & 3 & 6 & 0 & 30 & 45 \\
\hline & $\begin{array}{l}\text { \% within } \\
\text { Race }\end{array}$ & $4.4 \%$ & $8.9 \%$ & $6.7 \%$ & $13.3 \%$ & $.0 \%$ & $66.7 \%$ & $100.0 \%$ \\
\hline \multirow[t]{2}{*}{ Caucasian } & Count & 1 & 4 & 6 & 5 & 2 & 24 & 42 \\
\hline & $\begin{array}{l}\text { \% within } \\
\text { Race }\end{array}$ & $2.4 \%$ & $9.5 \%$ & $14.3 \%$ & $11.9 \%$ & $4.8 \%$ & $57.1 \%$ & $100.0 \%$ \\
\hline \multirow[t]{2}{*}{ Total } & Count & 3 & 8 & 9 & 11 & 2 & 54 & 87 \\
\hline & $\begin{array}{l}\text { \% within } \\
\text { Race }\end{array}$ & $3.4 \%$ & $9.2 \%$ & $10.3 \%$ & $12.6 \%$ & $2.3 \%$ & $62.1 \%$ & $100.0 \%$ \\
\hline
\end{tabular}

Thus, there is partial support for Hypothesis 2B2. While barriers were reported to seeking and receiving medical and psychological services following assault, there were no racial differences in perceptions of these barriers.

Hypothesis 2C1: African American women will report receiving less medical and psychological care and will report more problems receiving this care than Caucasian women.

As shown in Appendix D, this is also a complicated hypothesis with many interview items used to explore it, in dimensions of Reasons for Dissatisfaction with Medical Care, Race/Ethnicity as a Factor in How Treated, Perpetrator's Race/Ethnicity as a Factor in How Treated, Perpetrator Arrest Status, Case Prosecution Status, and Biggest Difficulty in the Treatment Experience. Findings in each of these dimensions are presented in the following: $\underline{\text { Reasons for Dissatisfaction with Medical Care }}$

African American women reported that lack of empathy was the major reason for dissatisfaction with medical care $(\mathrm{n}=8)$ : 
“It was very clinical, non-feeling. I felt like I was being violated all over."

"They were so cruel to me. I was just a number. The nurse made the advocate hurry up and finish because she said that she is only paid for a block of time. She was dismissing the evidence as she went along. [When she saw bruising to my uterus] she said "well that could have happened just from douching."

$\underline{\text { Race/Ethnicity as a Factor in How Treated }}$

Overall, African American women were more likely to express that race was a factor in response (Pearson Chi-square $=7.872, \mathrm{df}=2, \mathrm{p}=.020^{*}$ ) as further presented in Table 31.

Table 31. Reports of Race as a Factor in Response

\begin{tabular}{|c|c|c|c|c|c|}
\hline \multirow[b]{2}{*}{ Race } & & \multicolumn{3}{|c|}{$\begin{array}{l}\text { Race/ethnicity a factor in how people } \\
\text { responded to you }\end{array}$} & \multirow[b]{2}{*}{ Total } \\
\hline & & No & Yes & $\mathrm{N} / \mathrm{A}$ & \\
\hline \multirow[t]{2}{*}{ African American } & $\mathrm{N}$ & 85 & 34 & 2 & 121 \\
\hline & $\begin{array}{l}\% \text { within } \\
\text { Race }\end{array}$ & $70.2 \%$ & $28.1 \%$ & $1.7 \%$ & $100.0 \%$ \\
\hline \multirow[t]{2}{*}{ Caucasian } & $\mathrm{N}$ & 63 & 9 & 0 & 72 \\
\hline & $\begin{array}{l}\% \text { within } \\
\text { Race }\end{array}$ & $87.5 \%$ & $12.5 \%$ & $.0 \%$ & $100.0 \%$ \\
\hline \multirow[t]{2}{*}{ Total } & $\mathrm{N}$ & 148 & 43 & 2 & 193 \\
\hline & $\%$ within Total & $76.7 \%$ & $22.3 \%$ & $1.0 \%$ & $100.0 \%$ \\
\hline
\end{tabular}

Qualitative analyses revealed several themes reported by African American women pertaining to how they feel their race affected how people responded to them around the sexual assault. Frequent themes (number of times counted in parentheses) reported by African American women were racism (17), stereotypes about poverty (6), not being perceived as a victim (6), and drugs/prostitution (5).

\section{Racism}

"You know how white folks are. Because I'm black they don't give a shit."

\section{Poverty}

"I think they expected it to happen. It happens with poor people because who else is gonna want them?” 


\section{Not perceived as a "victim"}

"Because it looks like black women are more aggressive or at least that's what most people seem to think."

\section{Drugs/prostitution}

"It played a big part of when people were like 'she's probably either a crackhead, ho, prostitute' - all those stereotypes."

\section{Perpetrator's Race/Ethnicity as a Factor in How Treated}

Most women did not feel that the race of the perpetrator was a factor in how they were treated (81\% of African American and 77\% of Caucasian women said it was not a factor; Pearson Chi-square $=2.085, \mathrm{df}=2, \mathrm{p}=.353$ ). Further sub-analyses suggest that Caucasian women with a high level of education (bachelor's degree and above) were more likely to believe race of perpetrator was a factor in how they were treated (Pearson Chi-square $=5.62, \mathrm{df}=1, \mathrm{p}=.018^{*}$ ), as further presented in Table 32.

Table 32. Reports of Race of Perpetrator as a Factor in Response

\begin{tabular}{|c|c|c|c|c|}
\hline \multirow{2}{*}{ Race } & & \multicolumn{2}{|c|}{$\begin{array}{l}\text { Race/ethnicity of perpetrator a factor in how } \\
\text { people responded to you }\end{array}$} & \multirow[t]{2}{*}{ Total } \\
\hline & & No & Yes & \\
\hline \multirow{2}{*}{$\begin{array}{l}\text { High education African } \\
\text { American }\end{array}$} & $\mathrm{N}$ & 17 & 3 & 20 \\
\hline & $\begin{array}{l}\text { \% within } \\
\text { Race }\end{array}$ & $85.0 \%$ & $15.0 \%$ & $100.0 \%$ \\
\hline \multirow[t]{2}{*}{ High education Caucasian } & $\mathrm{N}$ & 6 & 7 & 13 \\
\hline & $\begin{array}{l}\% \text { within } \\
\text { Race }\end{array}$ & $46.2 \%$ & $53.8 \%$ & $100.0 \%$ \\
\hline \multirow[t]{2}{*}{ Total } & & 23 & 10 & 33 \\
\hline & $\%$ within Total & $69.7 \%$ & $30.3 \%$ & $100.0 \%$ \\
\hline
\end{tabular}

Some of the Caucasian women felt that reactions were worse if the perpetrator was a man of color, and some felt is was worse if the perpetrator was also Caucasian $(\mathrm{n}=13)$ : 
“He was Lebanese so for my sister it worsened things. I don't think it mattered to anyone else."

"Because he's a white male. If it had been a black man it would have been COMPLETELY different - they would have TOASTED him.”

"I think that the fact that we were of the same race made the focus about me and my needs. Had the race been different the focus of others would have been about his race and less about my needs."

"If he had been black they may have been more willing to be on my side, supportive."

"From some I got a 'you shoulda known better than to be flirty with a black man."'

\section{Perpetrator Arrest Status}

Of the women who reported the assault to the police, about $70 \%$ said the perpetrator was arrested, with no difference based on race (Pearson Chi-square $=.001, \mathrm{df}=1, \mathrm{p}=.971$ ), as further presented in Table 33.

Table 33. Reports of Arrest Status of Perpetrators

\begin{tabular}{|c|c|c|c|c|}
\hline \multirow[b]{2}{*}{ Race } & & \multicolumn{2}{|c|}{$\begin{array}{l}\text { Was person who } \\
\text { assaulted arrested }\end{array}$} & \multirow[b]{2}{*}{ Total } \\
\hline & & No & Yes & \\
\hline \multirow[t]{2}{*}{ African American } & $\mathrm{N}$ & 12 & 28 & 40 \\
\hline & $\begin{array}{l}\text { \% within } \\
\text { Race }\end{array}$ & $30.0 \%$ & $70.0 \%$ & $100.0 \%$ \\
\hline \multirow[t]{2}{*}{ Caucasian } & $\mathrm{N}$ & 7 & 16 & 23 \\
\hline & $\begin{array}{l}\text { \% within } \\
\text { Race }\end{array}$ & $30.4 \%$ & $69.6 \%$ & $100.0 \%$ \\
\hline \multirow[t]{2}{*}{ Total } & $\mathrm{N}$ & 19 & 44 & 63 \\
\hline & $\%$ within Total & $30.2 \%$ & $69.8 \%$ & $100.0 \%$ \\
\hline
\end{tabular}

\section{$\underline{\text { Case Prosecution Status }}$}

There was also no difference in whether or not the case was prosecuted based on the race of the victim (Pearson Chi-square $=.181, \mathrm{df}=1, \mathrm{p}=.670$ ), as further presented in Table 34 . 
Table 34. Reports of Prosecution Status of Perpetrators

\begin{tabular}{|l|l|r|r|r|}
\hline \multirow{2}{*}{ Race } & & \multicolumn{2}{|c|}{ Case was prosecuted } & \multirow{2}{*}{ Total } \\
\cline { 3 - 4 } & & No & \multicolumn{1}{c|}{ Yes } & 24 \\
African American & $\mathrm{N}$ & 7 & 17 & $29.2 \%$ \\
Caucasian & $\%$ within & $70.8 \%$ & $100.0 \%$ \\
& Race & 4 & 7 & 11 \\
Total & $\mathrm{N}$ & $36.4 \%$ & $63.6 \%$ & $100.0 \%$ \\
& $\%$ within & 11 & 24 & 35 \\
& Race & $31.4 \%$ & $68.6 \%$ & $100.0 \%$ \\
\hline
\end{tabular}

\section{Biggest Difficulty in the Treatment Experience}

At the end of the interview, the survivors were asked, "Looking back what was the biggest problem or difficulty you had in your sexual assault treatment experience?" Each response was coded into themes, and then the number of times each theme appeared was calculated as approximate percentages. These are presented in the Table 35 below.

Table 35. Themes Related to the "Biggest Problem” in the Treatment Experience

\begin{tabular}{|c|c|c|c|l|}
\hline $\begin{array}{l}\text { Overall } \\
\text { Percentage }\end{array}$ & $\begin{array}{c}\text { African } \\
\text { American } \\
(\mathrm{n})\end{array}$ & $\begin{array}{c}\text { Caucasian } \\
(\mathrm{n})\end{array}$ & $\begin{array}{l}\text { Total } \\
(\mathrm{n})\end{array}$ & Theme \\
\hline $19 \%$ & 19 & 11 & 30 & Did not tell because of fear, shame, or guilt \\
\hline $16 \%$ & 14 & 11 & 25 & Issues with law enforcement, lawyers, prosecutors, etc. \\
\hline $15 \%$ & 17 & 6 & 23 & Disbelief/lack of support from family and/or friends \\
\hline $10 \%$ & 9 & 7 & 16 & $\begin{array}{l}\text { Withdrawal, PTSD symptoms (nightmares, anger outbursts, } \\
\text { flashbacks, etc.) }\end{array}$ \\
\hline $8 \%$ & 7 & 5 & 12 & Knew the perpetrator \\
\hline $8 \%$ & 11 & 1 & 12 & Abuse happened in childhood \\
\hline $6 \%$ & 7 & 3 & 10 & Serious illness/injuries \\
\hline $5 \%$ & 1 & 7 & 8 & Finding a good therapist/treatment \\
\hline $5 \%$ & 6 & 2 & 8 & Inability to trust men \\
\hline $5 \%$ & 6 & 0 & 6 & Drugs and/or prostitution \\
\hline $3 \%$ & 4 & 1 & 5 & Did not know where or how to find treatment \\
\hline $100 \%$ & 100 & 54 & 155 & \\
\hline
\end{tabular}

We consulted a statistician who indicated it is appropriate to conduct nonparametric statistical analyses (as done throughout this report) on responses to the above question. This analysis indicated significant differences for responses of Abuse Happened in Childhood (Pearson Chi-square $=4.539, \mathrm{df}=1, \mathrm{p}=.035^{*}$ ), and Finding a Good Therapist (Pearson Chi- 
square $\left.=8.977, \mathrm{df}=1, \mathrm{p}=.005^{* *}\right)$. Thus, African American women were significantly more likely to report Childhood Abuse as the biggest problem, and Caucasian women were significantly more likely to report Finding Mental Health services as the biggest problem.

Thus, there is partial support for hypothesis 2C1, with African American women more likely to report race as a factor in the treatment experience and more likely to report unaddressed childhood abuse than Caucasian women.

Hypothesis 3: African American women will be more likely to utilize resources such as family, friends, and faith communities to deal with the aftermath of sexual assault than Caucasian women.

As above, a number of dimensions in the interview responses were used in exploring this hypothesis, including People Told about the Assault, Counseling Received from Clergy, Coping Strategies, and Most Helpful Services or Experiences. Findings in these realms are presented in the following.

People Told About the Assault

There was a different pattern of the first person told about the assault for African American as compared to Caucasian women (Pearson Chi-square=15.454, $\mathrm{df}=8, \mathrm{p}=.051^{*}$ ). African American women were more likely to first tell a relative, medical professional or no one at all, while Caucasian women were more likely to tell a friend first, as further presented in Table 36.

Table 36. Reports of the First Person Told

\begin{tabular}{|c|c|c|c|c|c|c|c|c|c|c|c|}
\hline \multirow[b]{2}{*}{ Race } & & \multicolumn{9}{|c|}{ First person victim told about the assault } & \multirow[t]{2}{*}{ Total } \\
\hline & & Relative & Friend & $\begin{array}{c}\text { 911- } \\
\text { police- } \\
\text { attorney }\end{array}$ & $\begin{array}{c}\text { Medical } \\
\text { professional }\end{array}$ & $\begin{array}{l}\text { Rape crisis } \\
\text { center }\end{array}$ & Clergy & Therapist & Other & $\begin{array}{l}\text { Told } \\
\text { no } \\
\text { one }\end{array}$ & \\
\hline African & $\mathrm{N}$ & 44 & 26 & 16 & 9 & 0 & 0 & 5 & 21 & 18 & 139 \\
\hline
\end{tabular}




\begin{tabular}{|c|c|c|c|c|c|c|c|c|c|c|c|}
\hline \multirow{3}{*}{$\begin{array}{l}\text { American } \\
\text { Caucasian }\end{array}$} & $\begin{array}{l}\% \\
\text { within } \\
\text { Race }\end{array}$ & $31.6 \%$ & $18.7 \%$ & $11.5 \%$ & $6.5 \%$ & $.0 \%$ & $.0 \%$ & $3.6 \%$ & $15.1 \%$ & $12.9 \%$ & $100.0 \%$ \\
\hline & $\mathrm{N}$ & 21 & 26 & 8 & 1 & 1 & 1 & 3 & 18 & 4 & 83 \\
\hline & $\begin{array}{l}\% \\
\text { within } \\
\text { Race }\end{array}$ & $25.3 \%$ & $31.3 \%$ & $9.6 \%$ & $1.2 \%$ & $1.2 \%$ & $1.2 \%$ & $3.6 \%$ & $21.7 \%$ & $4.8 \%$ & $100.0 \%$ \\
\hline \multirow[t]{2}{*}{ Total } & & 65 & 52 & 24 & 10 & 1 & 1 & 8 & 40 & 22 & 223 \\
\hline & $\begin{array}{l}\% \\
\text { within } \\
\text { Total }\end{array}$ & $29.1 \%$ & $23.3 \%$ & $10.8 \%$ & $4.5 \%$ & $.4 \%$ & $.4 \%$ & $3.6 \%$ & $17.9 \%$ & $9.9 \%$ & $100.0 \%$ \\
\hline
\end{tabular}

The women reported a variety of reasons for choosing that first person to tell about the sexual assault, as further presented in Table 37.

Table 37. Reason for Choosing the First Person Told

\begin{tabular}{|c|c|c|l|}
\hline $\begin{array}{c}\text { African } \\
\text { American } \\
(\mathrm{n})\end{array}$ & $\begin{array}{c}\text { Caucasian } \\
(\mathrm{n})\end{array}$ & Total & Theme \\
\hline 9 & 7 & 16 & Trust \\
\hline 3 & 3 & 6 & Shared experience of sexual assault \\
\hline 5 & 3 & 8 & First person available \\
\hline 6 & 3 & 9 & Thought person would be helpful \\
\hline 5 & 2 & 7 & Unable to hide assault \\
\hline 28 & 18 & 46 & \\
\hline
\end{tabular}

Many women chose people that they trusted:

"She had been very close to me and had supported me in previous years and had become like a second parent to me.” (AA)

“Because I felt like he would understand better than anyone.” (C)

"She was my best friend - she shared a confidential thing with me - it was first time I felt comfortable sharing.” (C)

Some women felt most comfortable talking to someone else who had had a similar experience:

“He had told me about someone touching him (a man)." (AA)

"Because I felt that all those incidences all the way growing up and that incident because I started using drugs when I was 23, I figured if I talked about it I'd be okay. And I found out I wasn't the only one. There was another girl in there who experienced the same thing. She was in foster care and it happened to her." (AA) 
Some women told the first person available:

"She was the first person I saw and I remember that I had passed her house before it happened." (AA)

"Because she was the only person there, first person I was alone with.” (C)

Some women talked to the person she thought would be most helpful:

"Because I wanted to get to the source of the problem. I didn't know who else to go to and I thought they would help me.” (AA)

Sometimes the women couldn’t hide it:

"Because she knew something had happened. She did not like the way I was behaving, she confronted me.” (AA)

"I came into the house and he could see right away." (C)

The women reported a wide range of reactions from the people that they told. Some women reported positive, supportive reactions, while others reported very negative reactions, as further presented in Table 38.

Table 38. Reactions of the First Person Told

\begin{tabular}{|c|c|c|l|}
\hline $\begin{array}{c}\text { African } \\
\text { American } \\
(\mathrm{n})\end{array}$ & $\begin{array}{c}\text { Caucasian } \\
(\mathrm{n})\end{array}$ & Total & Theme \\
\hline 16 & 7 & 23 & Supportive \\
\hline 9 & 10 & 19 & Resonant emotional response \\
\hline 12 & 5 & 17 & Shock \\
\hline 7 & 10 & 17 & Anger \\
\hline 10 & 4 & 14 & Negative emotions/indifference \\
\hline 5 & 8 & 13 & Tried to get help \\
\hline 5 & 5 & 10 & Disbelief \\
\hline 64 & 49 & 113 & \\
\hline
\end{tabular}

Some women reported that the person they told responded with shock:

“He said "what? Are you serious?” He was shocked. He was angry." (AA)

"She was in shock. We both were in shock. We cried." (AA)

Some responded with support and understanding: 
"He really felt sorry for me. Consoled me and everything. I would have nightmares and he would console me and talk to me.” (AA)

"He was very sympathetic, said that he understand why I act the way I act sometimes." $(\mathrm{AA})$

“Was comforting, offered support, listened.” (C)

Some listeners responded by trying to get the survivor help:

"Started crying. Took me to Laurel Hospital - they couldn't do nothing because it happened in another county. Then they took me to PG hospital but they couldn't do anything because it happened in another county but they offered for me to talk to a counselor, but I didn't want to talk to a counselor... just listened to what she had to say for a minute." (AA)

"I was hysterical and they immediately drove me to a police car parked nearby a 7eleven.” $(C)$

Some women reported a resonant emotional response in the person that they told about the assault:

“Hysterical.” (A and C)

"She was devastated. She just wanted to do whatever she could to help. She encouraged me to call someone at home. I was a foreigner in that tiny town and could not face that." $(C)$

"He was angry at my current husband who raped me and he told me to share this with my therapist." (C)

"She was sad for me and angry he had violated me." (C)

A number of women reported negative responses from the person that they told:

"We were in a car and he kicked me out of the car on the highway. He acted like it was my fault. He got mad at me. After that I didn't tell a lot of people because I was afraid other people would get upset with me.” (C)

"She was angry with them, but beat me." (C) 
Sometimes the negative reaction included the survivor being told that she was not believed or that the assault did not matter:

"She didn't believe me and threw me out of the house. That's how I got on the streets." (AA)

"She was just as worse as him. She didn't want to hear it. She told me to go on upstairs and stop telling lies.” (AA)

"She got mad and beat me and told me to stop telling lies." (AA)

"Initially they just took notes and just asked for everything that went on. As time went on they didn't believe me and just grilled me. They treated me like a criminal - like worse than a criminal...” (C)

"Told her I woke up the next day. Condoms all over the floor. She changed one day she believed me and the next day she didn't. You had to move. She told me she had called to see if I was ready to be picked up. My rapist told her I was okay and he'd bring me home." $(C)$

Sometimes the listener responded with indifference:

"Advised me to go to the hospital - very nonchalant really. They weren't attentive to me at all. Never took it to court or anything. And I attribute it to me being a substance abuser - they treated me like it." (AA)

"She didn't even really acknowledge it." (C)

"Oh, you know the attitude you brought it on yourself. No compassion, no sympathy, just didn't care. It is a good old boy network.” (C)

The survivors reported a number of reactions that made them feel that the person they

told either did or did not believe them? The survivor reported that she felt believed if the person

offered emotional support or practical assistance:

\section{Offered Emotional Support}

“Grabbed and held me.” (AA)

"Just because of the way he looked at me, he was consoling me - it wasn't like he was asking questions dissecting what I told him - he just listened."

"Because he said that he knew that something had happened." (AA) 
"She was understanding. That's how I could tell she believed me and she told me it happened to her." (AA)

\section{Offered practical assistance}

"She kept reinforcing the issue of getting medical assistance; make sure I was secure where I was, proactive about preventing subsequent encounters.” (AA)

"The first officer believed it because they went into the apartment to look for him. He was very stern about me going to the hospital so something could be done." (AA)

Some women did not feel that they were believed because of assumptions people made about their backgrounds:

"Because they knew me from being out there. The way I looked. They just knew it was prostitution. But prostitution and rape are two different things. They just thought I didn't get my money. And that's NOT what happened. I was forced in the car and was raped." (AA)

Some survivors felt that the person they told didn't believe them because that person responded by ignoring them or blaming them:

"Mother didn't believe me. We lived in a small town where everything was kept hushhush. Didn't want to tell me about sex. I learned the hard way. Said she didn't believe me. That's why she didn't do anything about it." (C)

"She told me 'see you shouldn't put yourself in that situation.” (C)

\section{$\underline{\text { Received Counseling from Clergy }}$}

African American and Caucasian women were equally unlikely to receive counseling services from their church or pastor (Pearson Chi-square=.026, $\mathrm{df}=1, \mathrm{p}=.87$ ), as further presented in Table 39. However, African American women were more likely to use religion as a way to cope with the aftermath of sexual assault than Caucasian women (Table 40).

\section{Table 39. Reports of Receiving Counseling from Clergy}




\begin{tabular}{|ll|r|r|r|}
\hline \multirow{2}{*}{ Race } & \multicolumn{2}{|c|}{$\begin{array}{c}\text { Received counseling } \\
\text { from church/pastor }\end{array}$} & Total \\
\cline { 3 - 5 } & No & Yes & \\
\hline African American & $\mathrm{N}$ & 40 & 6 & 46 \\
& $\%$ within Race & $87.0 \%$ & $13.0 \%$ & $100.0 \%$ \\
Caucasian & $\mathrm{N}$ & 37 & 5 & 42 \\
& $\%$ within Race & $88.1 \%$ & $11.9 \%$ & $100.0 \%$ \\
Total & $\mathrm{N}$ & 77 & 11 & 88 \\
& $\%$ within Total & $87.5 \%$ & $12.5 \%$ & $100.0 \%$ \\
\hline
\end{tabular}

\section{Coping Strategies}

The survivors were asked what strategies they used in coping with the aftermath of the sexual assault. Percentages of each qualitative theme are presented for 193 responses in Table 40.

Table 40. Reports of Survivor Coping Strategies

\begin{tabular}{|c|c|c|c|l|}
\hline $\begin{array}{l}\text { Overall } \\
\text { Percentage }\end{array}$ & $\begin{array}{c}\text { African } \\
\text { American } \\
(\mathrm{n})\end{array}$ & $\begin{array}{c}\text { Caucasian } \\
(\mathrm{n})\end{array}$ & $\begin{array}{c}\text { Total } \\
(\mathrm{n})\end{array}$ & Theme \\
\hline $27 \%$ & 31 & 22 & 53 & Denial/Tried to forget by focusing on work, school, family, etc. \\
\hline $25 \%$ & 32 & 18 & 50 & Sex, Drugs, and Alcohol \\
\hline $18 \%$ & 28 & 7 & 35 & Religion/God \\
\hline $9 \%$ & 5 & 12 & 17 & Counseling \\
\hline $4 \%$ & 5 & 3 & 8 & Exercise/Sports \\
\hline $4 \%$ & 3 & 4 & 7 & Isolation \\
\hline $3 \%$ & 4 & 3 & 7 & Overeating/Weight gain \\
\hline $3 \%$ & 2 & 3 & 5 & Suicide Attempts/Cutting \\
\hline $3 \%$ & 2 & 2 & 4 & Dealing with issues upfront \\
\hline $2 \%$ & 2 & 1 & 3 & Engaging in advocacy work \\
\hline $2 \%$ & 2 & 1 & 3 & Leaving situation/environment \\
\hline $100 \%$ & 116 & 76 & 192 & \\
\hline
\end{tabular}

In the above, there were two significant differences. African American women were more likely to use Religion/God to cope with the assault (Pearson Chi-square $=5.268, \mathrm{df}=1, \mathrm{p}=.023^{*}$ ), while Caucasian women were more likely to use counseling (Pearson Chi-square $=8.769$, $\mathrm{df}=1$, $\left.\mathrm{p}=.007^{* *}\right)$.

\section{$\underline{\text { Most Helpful Services or Experiences }}$}


Finally, the survivors were asked what service or experience was the most helpful to them. They reported a range of helpful experiences, with the most frequently helpful being counseling services. There were a total of 150 responses, as presented in Table 41.

Table 41. Reports of Most Helpful Services or Experiences

\begin{tabular}{|l|c|c|c|l|}
\hline $\begin{array}{l}\text { Overall } \\
\text { Percentage }\end{array}$ & $\begin{array}{c}\text { African } \\
\text { American } \\
(\mathrm{n})\end{array}$ & $\begin{array}{c}\text { Caucasian } \\
(\mathrm{n})\end{array}$ & $\begin{array}{c}\text { Total } \\
(\mathrm{n})\end{array}$ & Theme \\
\hline $38 \%$ & 28 & 29 & 57 & Counseling services \\
\hline $17 \%$ & 15 & 10 & 25 & Supportive family and friends \\
\hline $10 \%$ & 8 & 7 & 15 & Rape Crisis/Domestic Violence Centers Overall \\
\hline $7 \%$ & 4 & 7 & 11 & Law Enforcement \\
\hline $7 \%$ & 11 & 0 & 11 & Medical Personnel \\
\hline $6 \%$ & 5 & 5 & 10 & God/Religion \\
\hline $4 \%$ & 4 & 2 & 6 & Perpetrator Incarcerated \\
\hline $3 \%$ & 2 & 2 & 4 & Crisis Hotline \\
\hline $3 \%$ & 3 & 1 & 4 & Leaving relationship/environment \\
\hline $3 \%$ & 3 & 1 & 4 & This interview process \\
\hline $2 \%$ & 0 & 3 & 3 & Being incarcerated and mandated to participate in various programs \\
\hline $100 \%$ & 83 & 67 & 150 & \\
\hline
\end{tabular}

In the above, there were also two significant differences. Caucasian women were more likely to report that counseling was the most helpful experience for them (Pearson Chi-square $=$ 20.209, $\mathrm{df}=1, \mathrm{p}=.000^{* * *}$ ), while African American women were more likely to report that Medical Personnel were the most helpful experience for them (Pearson Chi-square $=6.860$, $\left.\mathrm{df}=1, \mathrm{p}=.008^{* *}\right)$

Thus, there is mixed support for Hypotheses 3. On the one hand both African American and Caucasian women were more likely to first tell a relative (AA) or a friend (C) of the assault. However, there were clear trends for Caucasian women to be more likely to use counseling as a coping strategy and to rate it as the most helpful experience, while African American women were more likely to use Religion/God as a coping strategy and to rate medical personnel as the most helpful experience.

\section{Differences in Findings Based on Setting}


As presented earlier, 96 participants were from Rape Crisis Centers, 62 were from Other Social Service Agencies, 63 were from Detention Centers, and 1 was interviewed at a University. To explore differences in findings based on setting we first compared Rape Crisis Center versus Other Social Service participants on a number of key variables as presented in the former analyses. There were no significant differences on any of these variables for these two groups of participants, except for the expected difference in whether the two groups received services from a sexual assault crisis center $(\mathrm{p}=.000)$. Hence, in subsequent analyses, these two groups (total $\mathrm{N}$ $=158$ ) were treated as one sample, which was compared to the Detention Center Sample. Please note that data from the one participant interviewed in a University were not included in these analyses. Again, for key variables as in the previous section, we explored comparisons between participants in the combined Community sample versus those in Detention Centers. The following significant differences (as before, all using the Pearson Chi-Square analysis, all with one DF) were found. Please note that related to a different response to each question Ns vary. Also, please note that we do not do a four-way analysis (African American, Caucasian, Detention Center, Community Setting) here, related to the complexity of this analysis, which we believe warrants another separate report:

1) Forty-three percent ( $N=27$ yes, 63 total [27/63]) of Detention Center (DC) participants compared to 26\% (42/159) of Community Setting (CS) participants reported the perpetrator was a stranger $(\mathrm{p}=.017)$.

2) Twenty-six percent of DC (16/62) versus $46.5 \%$ of CS (73/157) told the police about their assault $(\mathrm{p}=.005)$.

3) Zero percent of DC (0/44) versus $12 \%$ of CS (9/74) planned to file criminal charges against the perpetrator $(\mathrm{p}=.012)$. 
4) Twenty-six percent of DC (16/62) versus 47\% of CS (74/156) sought medical care after the assault $(\mathrm{p}=.003)$.

5) Three percent of DC (2/62) versus 35\% of CS (55/157) received services from a SACC $(\mathrm{p}=.000)$.

6) Fifteen percent of DC (9/61) versus 52\% of CS (80/154) received counseling services from a site or professional other than a SACC $(\mathrm{p}=.000)$.

\section{DISCUSSION}

This study, Sexual Assault in Maryland: The African American Experience involved two components, four focus groups with stakeholders who interact frequently with victims of sexual assault (e.g., forensic nurse examiners, rape crisis center and domestic violence center staff, hospital staff), and interviews conducted with 224 sexual assault survivors, 139 of whom were African American, and 83 of whom were Caucasian (with two participants who would not selfidentify in either race category).

As mentioned earlier, resource and logistical difficulties constrained our ability to meet the targeted enrollment of 500 participants in the study based on prior power analyses, so results of the interview portion of the study need to be interpreted with caution. However, we should add that of 11 studies presented in the literature review that included specific Ns for African American as compared to Caucasian women, only 3 exceeded the $\mathrm{N}$ in the present study, with the other 8 studies all having Ns of less than 170 .

We should also note that we have not controlled for experimentwise error for analyses that have been conducted. Should we have done this (e.g., with the Bonferoni correction), there would be almost no statistically significant findings for comparisons made based on race. Our 
rationale for not controlling for experimentwise error is to avoid obscuring trends in findings that may represent fruitful avenues of future research.

In general, focus group findings were consistent with the literature and included themes reflecting the need to reduce the stigma of seeking services, enhancing relevant education and outreach programs, improving the response of and eliminating biases in the legal system, and increasing the acceptability of mental health services for African American women. There was also a theme of African American women being focused on taking care of challenging circumstances for themselves and their families, with this serving as a barrier to seeking services for themselves, especially less “concrete” services such as counseling.

The major focus of the study was on conducting individual interviews with victims on their sexual assault and services experiences, with a multidimensional interview conducted face to face with participants. Process findings from conducting these interviews are important and emphasize the challenging nature of this research to both successfully recruit participants and gather data, and to conduct interviews in ways that are ethical and helpful to participants. This study encountered a number of practical, resource-related and logistical barriers in recruiting and interviewing participants, including those related to broadly publicizing the study, traveling to interview sites, negotiating "no shows” of participants, and sensitively handling both gathering data and being supportive and helpful to victims. A number of important lessons were learned for future research, underscoring the benefit and ethical appropriateness of face-to-face interviews (with interviewer and interviewee racial status matched for African American survivors), but also underscoring the resources and logistical planning needed to successfully carry out the research. Future studies should build purposefully into research designs strategies for broadly publicizing the opportunity for participation, negotiating logistical challenges such as 
travel and handling no shows, and should carefully consider possible enhancements in meaningful incentives to maximize recruitment and participation.

Timelines that reflect careful and realistic planning of public awareness, recruitment, and negotiating logistical challenges should also be built into research proposals. For example, in the current study, the one-year timeline for interview data collection initially proposed was unrealistic. Further, a sense of urgency about recruitment should reflect all phases of the study, even very early phases. In this project, we erroneously believed that slow progress of recruitment early on was expected and that we would catch up, which did not happen and resources to conduct the interviews ran out prematurely.

Relatedly, processes related to Institutional Review Board (IRB) Approval should be carefully considered when conducting sensitive research such as the current study with sexual assault survivors. While we were able to successfully obtain approval to conduct this study with incarcerated women in detention centers, and subsequently collected these data ethically and without incident, we did not realize the magnitude of actions required to accomplish this task, with six months of activities engaged in toward IRB approval.

Turning to interview findings, there were 8 specific hypotheses for this study. The hypotheses received no (1A, 1B) or mixed (2A1, 2A2, 2B1, 2B2, 2C1, 3) support. As mentioned, our failure to support these hypotheses may well relate to the fact that the study was most likely underpowered (at least in relation to our prior calculations which indicated a more desirable sample size of 500). Alternatively, related to problems in computing power calculations in novel areas of research with relatively unexplored constructs, findings may represent realistic estimates of themes presenting in broader populations. At a minimum, findings, in addition to illuminating process issues as above, point to directions for future research. We first review 
findings in more detail in relation to each hypothesis, then focus on other findings of note.

Please note that for some hypotheses there is little to add beyond what is in the Results section;

for others, there is more of a need for analysis and interpretation.

Hypothesis 1A: African American women will be more likely to experience sexual assault by a stranger than Caucasian women.

Here, around 33\% of African American women versus around 28\% of Caucasian women reported being assaulted by strangers, with no significant racial differences. In terms of related findings, we did find that Caucasian women were more likely to report $(\mathrm{p}=.02)$ being stalked by the perpetrator, a finding that was not presented in the literature.

Hypothesis 1B: African American women will be more likely to experience a greater intensity of assault (having a weapon used against them, greater force) than Caucasian women.

As presented earlier, intensity of assault was operationalized based on whether injuries occurred and whether a weapon was used; in both cases there were no racial differences.

However, we also explored differences in internal injuries and found that Caucasian women were more likely to report internal injuries from the attack $(\mathrm{p}=.03)$. Here, findings are inconsistent with those of Dearwater and colleagues (1998) who found higher rates of acute trauma from abuse for African American as compared to Caucasian and Hispanic women.

Hypothesis 2A1: Fewer African American women will indicate that they reported their sexual assault to police than Caucasian women.

Here, we found no overall differences based on race; however, when factoring in income, high income African American women were less likely to tell police of the assault than high income Caucasian women $(\mathrm{p}=.03)$. In interpreting this novel finding, Advisory Panel members 
suggested that African American women of high income may feel more stigma related to the incident and may "fear they have more to lose."

Hypothesis 2A2: African American women will indicate a number of racial and cultural barriers in reporting sexual assault to police.

As presented, this partially supported hypothesis was explored through analysis of a number of variables contributing to its analysis. African American women and Caucasian women were generally dissatisfied with their encounters with the police, with $25 \%$ and $36 \%$ (respectively) indicating they were "very dissatisfied" with the police interview, and 22\% and 43\% (respectively) indicating they were "very dissatisfied" with the way the police handled their case. Themes in analyses of qualitative responses of reasons for not reporting the assault by African American women included being young or naïve, being concerned about confidentiality, and wanting to move on.

Hypothesis 2B1: Fewer African American women will indicate that they sought medical and psychological services following sexual assault than Caucasian women.

There was mixed support for this hypothesis. In contrast with the studies by Resnick et al. (2000), which found that African American women were more likely to receive post rape medical care than Caucasians, and Campbell and colleagues $(1997,2001)$ who found the inverse, we found no significant difference in reported medical care received. However, when including income in the analysis, we did find that low income Caucasian women were less likely to seek medical care than low income African American women $(p=.004)$, a novel finding. Importantly, African American women were less likely to have received services from a sexual assault crisis center $(p=.032)$, were less likely to receive other counseling services $(p=.010)$ and were less likely to obtain services from a therapist or counselor $(\mathrm{p}=.024)$. These findings 
are consistent with those of Campbell and Bybee (1997), who found African American women to be less likely to receive information related to sexual assault, and with those of Campbell et al. (2001), who found that African American women were less likely to contact mental health professionals following rape. Similarly, Diala et al. (2001) reported that African American men and women were less likely to use mental health services than Caucasians.

Hypothesis 2B2: African American women will report a number of racial and cultural barriers in seeking and receiving medical and psychological services following sexual assault.

Related to the above mentioned findings of African American women being less likely to receive services from sexual assault crisis centers (SACCs), these women reported a number of barriers to these services, including not knowing about SACCs, being too young at the time of the assault to seek services, confidentiality concerns, and preferring to use family support. Although African American women were less likely to use SACC services, those women who did use them reported high satisfaction. For example, of a sample of 28 African American women who used these services, 26 or 93\% rated them as "good” or "very good.” Similarly, while African American women were less likely to receive psychological services, when they received them they were satisfied, with 22 of 23 women or $96 \%$ who received these services providing ratings of “satisfied” or "very satisfied.” For both African American and Caucasian women (with no significant racial differences) there were fairly long latencies between the assault and SACC and counseling services if they were received. For about half of the assault victims who connected to a SACC, it took over a year to connect to it, with not knowing about the SACC the major reason behind the delay (with no racial differences).

The one significant racial difference in findings related to this hypothesis was that Caucasian women were more satisfied with SACC hotline services than African American 
women $(p=.028)$. Based on our literature review this is a novel finding, which warrants further research.

Hypothesis 2C1: African American women will report receiving less medical and psychological care and will report more problems receiving this care than Caucasian women.

There is some overlap between this hypothesis and Hypothesis 2B1 related to the seeking of medical and psychological services. As presented earlier, there were no differences in medical services sought and received; however, African American women were less likely to seek and receive psychological services. In this hypothesis, we focus more on problems encountered in receiving these services. African American women were more likely to express that race was a factor in the response to their assault $(p=.02)$, with $28 \%$ of African American versus $12.5 \%$ of Caucasian women believing this. Qualitative analyses indicated that race was a factor in the perceptions of African American women in relation to a number of related variables including racism and stereotypes regarding poverty and involvement in drugs/prostitution. Of perpetrator variables including race, arrest status, and prosecution status, only race was a significant difference between the two groups of women; among high income women, Caucasians were more likely to believe race of the perpetrator was a factor in the response to them $(\mathrm{p}=.018)$. Based on our literature review, these are all novel findings that warrant further exploration of their significance for future research and policy agendas.

In terms of responses to the open-ended question pertaining to the "biggest problem in the treatment experience,” we did find significant differences in themes presented by participants. For African American women the biggest problem was that the "abuse happened in childhood” ( $\mathrm{p}=.035)$, whereas, for Caucasians, the biggest problem was "finding a good therapist” $(p=.005)$. Again, these findings are consistent with prior research (Campbell et al., 
2001; Diala et al., 2001) indicating that Caucasians both receive more and prefer mental health services more than African American women. These findings emphasize a multidimensional issue related to mental health services and sexually assaulted women that warrants further exploration of reasons for these differences and ways to enhance awareness of, attractiveness and appropriateness of mental health services for African American women. The finding that African American women were more likely to rate that abuse happened in childhood as the "biggest problem in the treatment experience” is novel and represents another area in need of further research.

Hypothesis 3: African American women will be more likely to utilize resources such as family, friends, and faith communities to deal with the aftermath of sexual assault than Caucasian women.

Here, there was a trend in the data for African American women to be more likely to first tell a relative, medical professional, or no one about the assault, while Caucasian women were more likely to first tell a friend. This finding is somewhat inconsistent with prior research of Robinson (2002) and Wyatt (1992), which indicated that African American adolescents and women are more likely to turn to family and friends for assistance following sexual assault. Results presented on pages 54-58 provide rich qualitative data on the first person told of the assault and their reactions. However, we do not discuss these results here as there were no clear trends based on race.

In contrast with trends in prior research, which suggest that African American women may be more likely to turn to clergy for support related to trauma than Caucasian women (e.g., Sims, 2002; Young, Griffith, \& Williams, 2003), we did not find this difference. However, in analyzing open-ended responses, we did find that African American women were more likely to 
use Religion/God as a coping strategy than Caucasian women $(\mathrm{p}=.023)$, consistent with the strong spiritual emphasis of the African American community (see Owens et al., 2004; Young et al., 2003).

In response to an open-ended question on the most helpful experience received, for Caucasian women this was counseling $(\mathrm{p}=.000)$, and for African American women this was medical personnel ( $\mathrm{p}$ - .008), again highlighting differences in the value placed on counseling by Caucasian women, and perhaps suggesting the value of other human interaction for African American women who were less likely to seek and to receive psychological services. This concludes the discussion of study findings in relation to hypotheses as presented in our grant application to NIJ. We now turn to findings related to incarcerated women.

Findings regarding incarcerated versus non-incarcerated women were in expected directions and highlight three major themes. First, detention center participants were more likely to be victims of strangers, which may be related to their increased risk taking, and being in unsafe environments. Second, detention center participants were clearly reticent about engaging with the police, either to tell them about the assault or to pursue the filing of criminal charges. This is likely related to past negative encounters with the police and/or fear of getting in additional trouble. Finally, there were very significant differences in the receipt of needed health and psychological services for detention center participants, underscoring a critical public health need to enhance outreach and effective services for these women. A number of these issues are discussed in a review article titled Prevalence and Severity of Lifetime Physical and Sexual Victimization Among Incarcerated Women by Browne, Miller and Maguin (1999). 


\section{Conclusion and Next Steps}

Notwithstanding the challenges to interpretation related to the fact that this study did not achieve the targeted number of participants of 500, findings can and should be used in discussions aimed at improving sexual assault services for African American and Caucasian women and building research agendas. For example, questions emerging from the study include: What are the most promising strategies to improve interactions between law enforcement staff and sexual assault victims?, What are the specific barriers that get in the way of receiving SACC and Mental Health services for African American women and how can they be overcome?, Why do Caucasian survivors apparently value mental health services more than African American Survivors?, How can Hotline or Crisis Line services be enhanced to better serve African American survivors?, How can we better understand the report of African American survivors of a major barrier to services being “ the Abuse Happened in Childhood?,” How can early identification and intervention programs targeting sexual assault be enhanced?, How can the use of spiritual coping strategies be strengthened?, and How can recruitment and enrollment in such sensitive research be enhanced? Guided forums on questions like these with diverse stakeholders including women of color who are survivors and advocates will help to build relevant service, policy and research avenues. While this federal grant has ended for our teams at the University of Maryland, and the Maryland Coalition Against Sexual Assault, we hope to play an active role in stimulating such dialogue. We extend our appreciation to the National Institute of Justice for the opportunity to conduct this study. 


\section{REFERENCES}

Ackerman, P.T., Newton, J.E.O., McPherson, W.B., Jones, J.G., \& Dykman, R.A. (1998). Prevalence of post traumatic stress disorder and other psychiatric diagnoses in three groups of abused children (sexual, physical, and both). Child Abuse \& Neglect, 22(8), 759-774.

Adisa, O.P. (1997). Undeclared war: African-American women writers explicating rape. In O’Toole, L.L. \& Shiffman, J.R. (Eds.) Gender violence: Interdisciplinary perspectives.

Barbee, E. (1999). Black women and mental health. Abafazi, 9(2), 52-64.

Boney-McCoy, S., \& Finkelhor, D. (1995) Psychosocial sequelae of violent victimization in a national youth sample. Journal of Consulting and Clinical Psychology, 63(5), 726-736.

Browne, A.M., Miller, B., \& Maguin, E. (1999). Prevalence and severity of lifetime physical and sexual victimization among incarcerated women. International Journal of Law and Psychiatry, 22, 301-322.

Bruns, E.J., Lewis, C.P., Kinney, L.M., Weist, M.D., \& Dantzler, J. (2005). Clergy members as responders to victims of sexual abuse and assault. Journal of Religion and Spirituality in Social Work, 24, 3-19.

Campbell, R. (1998). The community response to rape: Victim's experiences with the legal, medical, and mental health systems. American Journal of Community Psychology, 26(3), 355-378.

Campbell, R., \& Bybee, D. (1997). Emergency medical services for rape victims: Detecting the cracks in service delivery. Women's Health: Research on Gender, Behavior, and Policy, 3(2), 75-101.

Campbell, R. \& Raja S. (2005). The sexual assault and secondary victimization of female veterans: Help-seeking experiences with military and civilian social systems. Psychology of Women Quarterly, 29, 97-106.

Campbell, R., Wasco, S.M., Ahrens, C.E., Sefl, T., \& Barnes, H.E. (2001). Preventing the "second rape": Rape survivors experiences with community service providers. Journal of Interpersonal Violence, 16(12), 1239-1259.

Catalano, S. M. (2004, September). Bureau of Justice Statistics National Crime Victimization Survey: Criminal Victimization, 2003 (NCJ 205455). Washington, DC: U.S. Department of Justice.

Cheston, S.E. (1993). Counseling adult survivors of childhood sexual abuse. In Wick, R.J., Parsons, R.D. (Eds.), Clinical Handbook of Pastoral Counseling, Vol. 2. Studies in Pastoral Psychology, Theology, and Spirituality. (pp. 447-488). Mahwah, NJ: Paulist. 
Crime Victim Research and Treatment Center/ National Victim Center. (1992). Rape in America: A report to the nation. Arlington, VA: Author.

Dantzler, J., Weist, M.D., Kinney, L., \& Monroe, L. (2003). Sexual assault needs assessment project. Sexual Assault Reports, 6, 65-66.

Dearwater, S.R., Coben, J.H., Campbell, J.C., Nah, G., Glass, N., McLoughlin, E. \& Bekemeier, B. (1998). Prevalence of intimate partner abuse in women treated at community hospital emergency departments. JAMA, 280(5), 433-438.

Diala, C., Muntaner, C., Walrath, C., Nickerson, K., LaVeist, T.A., \& Leaf, P. (2001). Racial/ethnic differences in attitudes toward seeking professional mental health services. American Journal of Public Health, 91(5), 805-807.

Diala, C., Muntaner, C., Walrath, C., Nickerson, K.J., LaVeist, T.A., \& Leaf, P.J. (2000). Racial differences in attitudes toward professional mental health care and in the use of services. American Journal of Orthopsychiatry, 70(4), 455-464.

Ellis, E.M. (1983). A review of empirical rape research: Victim reactions and response to treatment. Clinical Psychology Review, 3, 473-490.

Fonow, M. M., Richardson, L., \& Wemmerus, V. A. (1992). Feminist rape education: Does it work? Gender \& Society, 6, 108-121.

Fouque, P., \& Glachan, M. (2000). The impact of Christian counselling on survivors of sexual abuse. Counselling Psychology Quarterly, 13, 201-220.

Fraizer, P., Rosenberger, S., \& Moore, N. (2000, August). Correlates of service utilization among sexual assault survivors. Poster session presented at the annual meeting of the American Psychological Association, Washington, DC.

George, L.K., Winfield, I., \& Blazer, D.G. (1992). Sociocultural factors in sexual assault: Comparison of two representative samples of women. Journal of Social Issues, 48(1), 105-125.

Holtzman, C.G. (1996). Counseling adult women rape survivors: Issues of race, ethnicity, and class. Women \& Therapy, 19(2), 47-62.

Hymes, R.W. \& Leinart, M. (1993). Acquaintance rape: The effect of race of defendant and race of victim on white juror decisions. Journal of Social Psychology, 133(5), 627-635.

Kalof, L. (2000). Ethnic differences in female sexual victimization. Sexuality \& Culture, 4(4), 75-97. 
Karjane, H.K., Fisher, B.S., \& Cullen, F.T. (2002). Campus sexual assault: How America's institutions of higher education respond. Final report, NIJ Grant \#199-WA-VX-0008. Newton, MA: Education Development Center, Inc.

Kaukinen, C. \& DeMaris, A. (2005). Age at first sexual assault and current substance use and depression. Journal of Interpersonal Violence, 20 (10), 1244-1270.

Kilpatrick, D.G., Best, C.L., Veromen, L.J., Amick, A.E., Villeponteaux, L.A., \& Ruff, G.A. (1985). Mental health correlates of criminal victimization: A random community survey. Journal of Counseling and Clinical Psychology, 53(6), 866-873.

Koss, M. P. (2005). Empirically enhanced reflections on 20 years of rape research. Journal of Interpersonal Violence, 20, 100-107.

LaFree, G.D. (1981). Official reactions to social problems: Police decisions in sexual assault cases. Social Problems, 28(5), 582-594.

Landwehr, P.H., Bothwell, R.K., Jeanmard, M., Luque, L.R., Brown, R.L., \& Breaux, M.A. (2002). Racism in rape trials. Journal of Social Psychology, 142(5), 667-670.

LaVeist, T.A. (2000). On the study of race, racism, and health: A shift from description to explanation. International Journal of Health Services, 30(1), 217-219.

Lillie-Blanton, M., \& LaVeist, T. (1996). Race/ethnicity, the social environment, and health. Social Science Medicine, 43(1), 83-91.

Marshall, C., \& Rossman, G. (1999). (3 ${ }^{\text {rd }}$ ed.). Designing qualitative research. Newbury Park, CA: Sage.

Nagel, B., Matsuo, H., McIntyre, K. P., \& Morrison, N. (2005). Attitudes toward victims of rape: Effects of gender, race, religion, and social class. Journal of Interpersonal Violence, 20 (6), 725-737.

National Institute of Justice. (2001). Broadening our understanding of violence against women among racial, ethnic, and cultural minorities: Workshop summary. Retrieved April 3, 2003 from the Office of Justice Programs website http://wwww.ojp.usdoj.gov/nij/vawprog/broadening.html.

National Research Council .(1996). Understanding violence against women. DC: National Academy Press.

McFarlane, J., Malecha, A., Watson, K., Gist, J., Batten, E., Hall, I., \& Smith S. (2005). Intimate partner sexual assault against women: Frequency, health consequences, and treatment outcomes. The American Journal of Obstetricians and Gynecologists, 105, 99-108. 
Neville, H., Heppner, M., Clark, M. (2004). General and Culturally specific factors Influencing Black and White Rape Survivors' Self-Esteem. Psychology of Women Quarterly, 28, 83-94.

Neville, H.A. \& Pugh, A.O. (1997). General and culture-specific factors influencing African American women's reporting patterns and perceived social support following sexual assault: An exploratory investigation. Violence Against Women, 3(4), 361-383.

Owens, C.C., Bryant, T.N., Huntley, S.S., Moore, E., Sloane, T., Hathaway, A., \& Weist, M.D. (2004). Enhancing child and adolescent resilience through faith-community connections. In C. Clauss-Ehlers, \& M.D. Weist (Eds.), Community planning to foster resilience in children_(pp. 283-296). New York, NY: KluwerAcademic/Plenum Publishers.

Priest, R. (1992). Child sexual abuse histories among African-American college students. American Journal of Orthopsychiatry, 62, 475-476.

Reid, P.T. \& Kelly, E. (1994). Research on women of color: From ignorance to awareness. Psychology of Women Quarterly, 18, 477-486.

Rennison, C.M. (2002). Rape and sexual assault: Reporting to police and medical attention, 1992-2000. (NCJ 194530). Washington, DC: U.S. Department of Justice.

Rennison, C.M. (2001). Violent Victimization and race, 1993-1998. (NCJ 176354) Washington, DC: U.S. Department of Justice.

Resick, P. A. (1987). Psychological effects of victimization: Implications for the criminal justice system. Crime Delinquency, 33(4), 468-478.

Resnick, H., Acierno, R., Holmes, M., Dammeyer, M., \& Kilpatrick, D. (2000). Emergency evaluation of intervention with female victims of rape and other violence. Journal of Clinical Psychology, 56(10), 1317-1333.

Robinson, L.S. (2002). I will survive. New York, NY: Seal Press.

Roth, S., \& Lebowitz, L. (1988). The experience of sexual trauma. Journal of Traumatic Stress, 1, 79-107.

Rozee, P.D. \& Koss, M.P. (2001). Rape: A century of resistance. Psychology of Women Quarterly, 25, 295-311.

Russell, D. E. H., \& Bolen, R. M. (2000). The epidemic of rape and child sexual abuse in the United States. Thousand Oaks, CA: Sage Publications.

Schafran, L. H. (1996). Topics for our times: Rape is a major public health issue. Editorial in American Journal of Public Health, 86(2), 15-17. 
Sims, M.J. (2002). Incest and child sexual abuse in the African American community: African American ministers' attitudes and beliefs (Doctoral dissertation, Alliant International University, 2002). Dissertation Abstracts International, 63(5-B), 2605.

Smith, S.K., Steadman, G.W., \& Minton, T.D. (1999). Criminal victimization and perceptions of community safety in 12 cities, 1998. (NCJ 173940) Washington, DC: U.S. Department of Justice.

Thompson, V.L.S. \& West, S.D. (1992). Attitudes of African American adults toward treatment in cases of rape. Community Mental Health Journal, 28(6), 531-536.

Tjaden, P. \& Thoennes, N. (2006). Special Report: Extent, Nature and Consequences of Rape Victimization: Findings from the National Violence Against Women Survey. Washington, DC: National Institute of Justice, U.S. Department of Justice.

Tjaden, P. \& Thoennes, N. (1998). Prevalence, incidence, and consequences of violence against women: Findings from the National Violence Against Women Survey, Research in Brief. Washington, DC: National Institute of Justice, U.S. Department of Justice.

Ullman, S.E., \& Filipas, H. H. (2001). Correlates of formal and informal support seeking in sexual assault victims. Journal of Interpersonal Violence, 16 (10), 1028-1047.

Ullman, S.E., \& Filipas, H.H. (2001). Predictors of PTSD symptom severity and social reactions in sexual assault victims. Journal of Traumatic Stress, 14(2), 383-387.

Von, J. M., Kilpatrick, D. G., Burgess, A. W., \& Hartman, C. R. (1991). Rape and sexual assault. In M. L. Rosenberg \& M. A. Fenley (Eds.) Violence in America: A public health approach. New York: Oxford University Press.

Washington, P. (2001). Disclosure Patterns of Black Sexual Assault Survivors. Violence against Women, 7(11), 1254-1284.

Wingood, G.M. \& DiClemente, R.J. (1998). Rape among African American women: Sexual, psychological, and social correlates predisposing survivors to risk of STD/HIV. Journal of Women's Health, 7(1), 77-84.

Winkel, F.W., \& deWinter, S. (1996). The perceived credibility of rape victims during a police interview: An experiment among victim assistance workers. In Davies, G. (Ed), LloydBostock, S. et al. Psychology, law, and criminal justice: International Developments in Research and Practice. New York: Waler de Gruyther, Inc.

Wyatt, G.E. (1992). The sociocultural context of African American and white American women’s rape. Journal of Social Issues, 48(1), 77-91. 

been published by the Department. Opinions or points of view expressed are those of the author(s) and do not necessarily reflect the official position or policies of the U.S. Department of Justice.

Young, J.L., Griffith, E.E.H., \& Williams, D.R. (2003). The integral role of pastoral counseling by African-American clergy in community mental health. Psychiatric Services, 54, 688-692. 


\section{Appendix A: Focus Group Questions and Themes in Responses}

\begin{tabular}{|c|c|}
\hline Focus Group Questions & Response Themes \\
\hline $\begin{array}{l}\text { 1) What do you view as the needs of } \\
\text { African American women who have } \\
\text { been sexually assaulted? Are these } \\
\text { different than women of other } \\
\text { racial/ethnic backgrounds? Why? }\end{array}$ & $\begin{array}{l}\text {-Need for transportation assistance } \\
\text { ("Potential clients call and say, 'How am I supposed to } \\
\text { get there...' “) } \\
\text {-Easier access to rape crisis centers } \\
\text {-Financial assistance for treatment } \\
\text {-Removal of stigma of therapy/ medication services } \\
\text {-Desire for diversity in counseling staff } \\
\text {-Education on safety (especially regarding "hacks” or } \\
\text { illegal cab drivers as sexual perpetrators) } \\
\text {-Education on acquaintance and statutory rape (based } \\
\text { on view that high levels of African American women } \\
\text { experience these phenomena) } \\
\text {-Lack of trust in professionals } \\
\text {-Encouraged not to report the sex offense to "outsiders” }\end{array}$ \\
\hline $\begin{array}{l}\text { 2) What issues have you } \\
\text { seen/experienced in how African } \\
\text { American victims of sexual assault are } \\
\text { treated by the criminal justice system } \\
\text { (law enforcement/prosecutor's } \\
\text { office/court system)? Do you perceive } \\
\text { unique barriers to reporting sexual } \\
\text { assault to police for African American } \\
\text { women? }\end{array}$ & $\begin{array}{l}\text {-Didn’t get reports from many African American } \\
\text { women and didn’t notice any difference } \\
\text {-For all clients police discourage prosecution if victim } \\
\text { was drinking or taking drugs } \\
\text { ("You are sure that is what it was? Do you think that's } \\
\text { what it was? This could ruin your life") } \\
\text {-Clients have expressed that they have experienced } \\
\text { racism from the police } \\
\text {-African American women are reluctant to help punish } \\
\text { an African American male even if he is the perpetrator } \\
\text { of sexual violence } \\
\text {-Reluctance of African American females to report an } \\
\text { African American male perpetrator for fear of him } \\
\text { being sent to jail } \\
\text {-Distrust of detectives of the same race } \\
\text {-Feels the system is against them and African } \\
\text { American men }\end{array}$ \\
\hline $\begin{array}{l}\text { 3) Are there unique issues to the use of } \\
\text { available resource by African } \\
\text { American women, such as post-rape } \\
\text { medical care and counseling services? } \\
\text { Do you perceive unique barriers to the } \\
\text { use of these services by African } \\
\text { American women? }\end{array}$ & $\begin{array}{l}\text {-No issues around post rape medical care } \\
\text { (“They all get equal access here”) } \\
\text {-African American women less likely to value post } \\
\text { rape counseling } \\
\text { "African American women don't know enough about } \\
\text { the aftermath of rape” } \\
\text { "African American women are just not coming in to the } \\
\text { hospitals to report” } \\
\text {-Do not accept mental health services } \\
\text {-African American women think being depressed or }\end{array}$ \\
\hline
\end{tabular}




\begin{tabular}{|c|c|}
\hline & $\begin{array}{l}\text { sad is the norm } \\
\text { ("It is a way of life for me. I can expect to be beaten } \\
\text { from Thursday night to Sunday morning”) } \\
\text {-Resources seen as limited due to lack of centers' level } \\
\text { of diversity } \\
\text { (One counselor called a "white, rich bitch”) } \\
\text {-Transportation and child care are issues they are ill } \\
\text { equipped to handle because the center does not have } \\
\text { money to assist } \\
\text {-Women of color believe they can and should handle } \\
\text { taking care of themselves ("You should pull yourself } \\
\text { together”) }\end{array}$ \\
\hline $\begin{array}{l}\text { 4) What issues have you } \\
\text { seen/experienced in outreach to } \\
\text { African American victims by your } \\
\text { agency? }\end{array}$ & $\begin{array}{l}\text {-Have not experienced any issues ( } 3 / 4 \text { of client base is } \\
\text { African American) } \\
\text {-There is the need to convey the unexpected prevalence } \\
\text { of sexual assault } \\
\text {-There is no one who has a sexual assault expertise in } \\
\text { the University Counseling Center } \\
\text {-Lack of phones and family resources } \\
\text {-African American women live in areas of increased } \\
\text { sexual violence } \\
\text {-Some hospitals have not done any outreach at all } \\
\text {-In public housing outreach, the African American } \\
\text { women are too busy improving their circumstances to } \\
\text { attend outreach programs } \\
\text {-African American families in need of more concrete } \\
\text { services due to economic reasons (housing, } \\
\text { employment) and less concerned about counseling } \\
\text {-Have had trouble deciding where to specifically target } \\
\text { outreach to African American women except through } \\
\text { the church } \\
\text {-Education is vital and family and community must } \\
\text { serve as partners in this process }\end{array}$ \\
\hline $\begin{array}{l}\text { 5) What are your key } \\
\text { recommendations for the state of } \\
\text { Maryland to improve services for } \\
\text { African American women who are } \\
\text { victims of sexual assault? }\end{array}$ & $\begin{array}{l}\text {-More outreach in African American colleges and } \\
\text { communities } \\
\text {-More female detectives working on sexual assault } \\
\text { cases } \\
\text {-More money put into outreach efforts and fund those } \\
\text { who can support those who disclose } \\
\text {-Increased resources to support counseling sessions for } \\
\text { victims } \\
\text {-Determine the viability of what is being offered - is it } \\
\text { culturally useful? } \\
\text {-More resources for public service announcements } \\
\text { (radio/TV/churches) }\end{array}$ \\
\hline
\end{tabular}




\begin{tabular}{|l|l|}
\hline & -Recruitment of African Americans to provide clinical \\
& services to sexual assault victims \\
& -Increased resources to explore alternative methods of \\
healing (art, drama, story-telling, crafts, meditation, \\
etc.) \\
-Need to research to find out what is happening in \\
schools and what education is open to girls \\
-Resources to train police officers in how to \\
competently work with sexual assault victims (specific \\
detectives to handle sexual assault) \\
-Resources to assist with legal aid of assault victims \\
-Resources for cultural competence training for key \\
personnel at all levels of sexual assault victim \\
assistance
\end{tabular}




\section{Appendix B: Number of Participants at Each Site for Study Interviews}

\begin{tabular}{|c|c|c|}
\hline & Frequency & Percent \\
\hline Family Crisis Resource Center & 5 & 2.2 \\
\hline Turn Around - Baltimore City & 15 & 6.7 \\
\hline Turn Around - Baltimore County & 17 & 7.6 \\
\hline Crisis Intervention Center & 1 & .4 \\
\hline For All Seasons & 1 & .4 \\
\hline Rape Crisis Intervention Services & 5 & 2.2 \\
\hline Cecil County Domestic Violence/Rape Crisis Center & 3 & 1.3 \\
\hline Center for Abused Persons & 7 & 3.1 \\
\hline Heartly House & 6 & 2.7 \\
\hline DOVE Center & 2 & .9 \\
\hline Sexual Assault/Spouse Abuse Resource Center & 4 & 1.8 \\
\hline STARR Center & 6 & 2.7 \\
\hline Victim Assistance and Sexual Assault Program & 9 & 4.0 \\
\hline Prince George's Hospital Center, Sexual Assault Center & 8 & 3.6 \\
\hline Walden-Sierra & 1 & .4 \\
\hline Life Crisis Center & 4 & 1.8 \\
\hline My Sister's Place & 54 & 24.0 \\
\hline MCASA Arnold & 2 & .9 \\
\hline Family Partnership of Frederick & 8 & 3.6 \\
\hline Charlotte Hall Facility (St. Mary’s) & 1 & .4 \\
\hline PG County Detention Center & 30 & 13.3 \\
\hline Washington County Detention Center & 14 & 6.2 \\
\hline Montgomery County Detention Center & 19 & 8.4 \\
\hline University of Maryland & 1 & .4 \\
\hline
\end{tabular}




\section{Appendix C: Study Interview Measure}

\section{Subject ID \#}

Interviewer Initials

Date

Subject race

Center

\section{INTERVIEW}

First, I want to honor the fact that you are here to tell me about your experience of sexual assault. By sharing your story, you will be helping other survivors of sexual assault. I also want to acknowledge that talking about your experience may be difficult for you or might bring up difficult feelings. I want to assure you that you are in a safe environment. You can take a break at any time during this interview. Counselors are available here at the center if you think if may be beneficial to speak with one. You also can decline to answer any question that you do not want to answer.

Are you ready to begin?

PERSONAL DEMOGRAPHICS - First, I am going to ask you some demographic questions.

1. What part of Maryland do you reside in?

$\begin{array}{ll}1 & \text { Western } \\ 2 & \text { Central } \\ 3 & \text { Eastern } \\ 4 & \text { Southern }\end{array}$

2. How would you describe where you live?
1 Urban
2 Suburban
3 Rural

3. What is your age?

4. What is your marital status?
1 Single
2 Married
3 Living in a committed relationship
4 Separate/Divorced
5 Widowed

5. What is the highest education level you completed?
1 Some high school
2 High school graduate or GED
3 Technical or Trade School
4 Associate's degree
5 Bachelor's degree
6 Master's degree 


\section{Doctoral degree}

6. What is your annual household income?

7. Do you receive any form of public assistance? 1 Yes $\quad 0 \quad$ No

IF NO, SKIP TO QUESTION 8.

What form of public assistance do you receive? (Circle all that apply.)

1 WIC

2 Medical Assistance (Medicare, Medicaid)

3 Housing Assistance

4 Income Assistance

5 Other

DETAILS OF THE SEXUAL ASSAULT - Now I will ask some questions about the sexual assault.

8. How long ago did the sexual assault take place?

(If individual indicates that more than one sexual assault took place, ask the person to focus on the most recent

assault.)

9. What was the relationship of the person who assaulted you?

1 Friend

2 Acquaintance

3 Spouse

4 Relative

5 Boyfriend

6 Girlfriend

7 Ex-spouse

8 Ex-boyfriend or girlfriend

9 Stranger

10 Date

11 Teacher

12 Boss

13 Friend of the family

14 Co-worker

15 Other, specify

10. What was the ethnicity of the person who assaulted you?

1 White

2 African-American

3 Asian/Pacific Islander

4 American Indian/Alaska Native

5 Hispanic

6 Other (specify):

7 Unknown

11. Was the person who attacked you under the influence of drugs and/or alcohol at the time of the assault?
1 Yes
0 No
7 Unknown 
12. Did the person who attacked you persuade you to use drugs and/or alcohol or put drugs into your drink prior to the assault?
1 Yes
$0 \quad$ No
7 Unknown

13. When you were assaulted, which of the following occurred? (Circle all that apply.)

1 Vaginal penetration with a penis

2 Vaginal penetration with a finger or foreign object

3 Oral sex

4 Anal penetration with a penis

5 Anal penetration with a finger or foreign object

6 Sexual touching

7 Other

14. Did you receive any other physical injuries in addition to the rape/sexual assault? 1 Yes 0 No

IF NO, SKIP TO QUESTION 16.

15. Please describe the physical injuries.

16. Did the person who assaulted you use a weapon?

1 Yes 0 No

\section{IF NO, SKIP TO QUESTION 17.}

What type of weapon was used?

1 Firearm

2 Knife

3 Blunt instrument

4 Other

17. Where did the assault take place?

18. Had you been stalked by the person who assaulted you? By stalking, I mean that the attacker followed you, made unwanted phone calls, or sent you letters or e-mails for an extended period of time.

\section{Yes 0 No}

19. Have you ever been sexually assaulted, molested, or raped by someone before this incident?

$$
1 \text { Yes } 0 \text { No }
$$

\section{IF NO, SKIP TO QUESTION 21}

20. Did you ever seek help when you were sexually assaulted, molested, or raped before?

1 Yes 0 No 
21. How long after the sexual assault was it before you told someone about it? (Fill in the appropriate blank below.)

hours or days or months or years

IF INDIVIDUAL NEVER TOLD ANYONE, SKIP TO QUESTION 31 UNDER MEDICAL CARE.ON PAGE 5

22. Who was the first person that you told about the sexual assault?

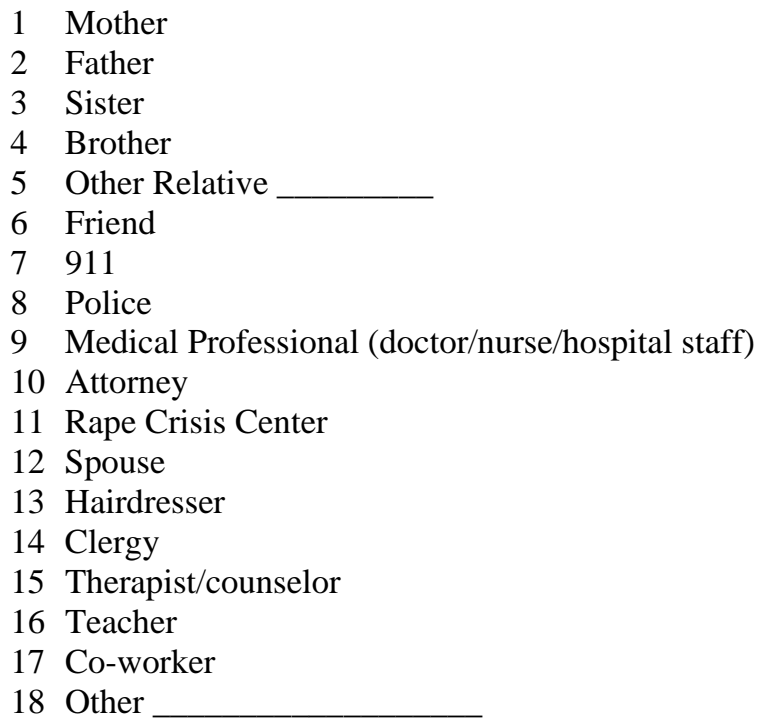

23. Why did you choose that person?

24. How did that person react when you told them?

25. Based on the person's reaction, did it appear that they believed you? 1 Yes

0 No

What made you think that they did or did not believe you?

26. Have you told anyone else? 1 Yes 0 No

IF NO, SKIP TO QUESTION 31 UNDER MEDICAL CARE ON PAGE 5.

27. Who else did you tell? (Circle all that apply.)

1 Mother

2 Father

3 Sister

4 Brother

5 Other Relative

6 Friend 


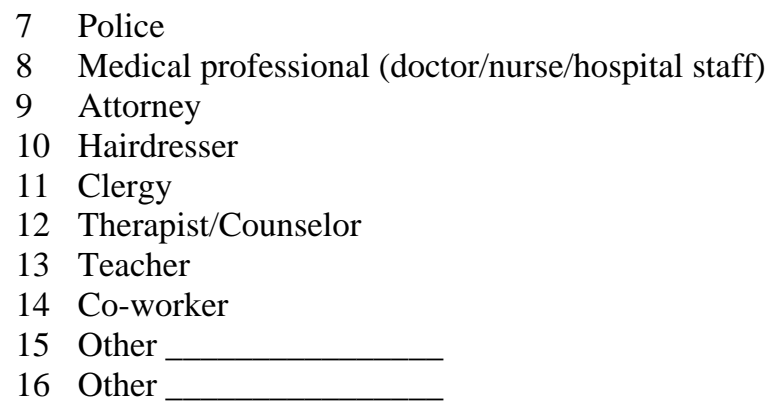

28. How did each person react when you told them? (If there is more than one person, write number (e.g.1), then the response for that person)

29. Based on the person's reaction, did it appear that they believed you? 1 Yes

0 No

30. What made you think that they did or did not believe you?

MEDICAL CARE - Now I am going to ask some questions about medical services.

31. Did you seek medical care in relation to the sexual assault? $\quad 1$ Yes $\quad 0$ No

IF YES, SKIP TO QUESTION 33.

32. Why did you not seek medical care?

SKIP TO QUESTION 50 UNDER LAW ENFORCEMENT ON PAGE 7.

33. How long after the assault did you have a medical examination?

34. What prompted you to seek care at a medical facility? (Circle all that apply.)

1 Injuries

2 Possible sexually transmitted disease

3 Possible pregnancy

4 Family suggestion

5 Friend suggestion

6 Police officer

7 Wanting to get evidence

8 Other (specify)

35. Did you tell the medical professionals that your visit/injuries had to do with being sexually assaulted?
1 Yes
0 No

36. Where did you receive medical treatment for the sexual assault?

1 Hospital

2 Clinic (Planned Parenthood, Community Health Clinic) 
3 Doctor's office (Family Practitioner, GYN)

4 Other

37. 'In what county did you receive the medical treatment services?

County:

38. Who performed the medical examination? (Circle all that apply.)

1 Physician

2 Nurse/Nurse practitioner

3 SAFE/SANE examiner

4 Don't know

39. Was a rape kit completed (collections of evidence)? $\quad \begin{array}{rrrr}1 & \text { Yes } & 0 & \text { No }\end{array}$

40. Did someone at the hospital tell you about forms of emergency contraception, such as the morning-after pill or Plan B, that were available? $\quad 1$ Yes 0 No

IF NO, SKIP TO QUESTION 42.

41. Did you take emergency contraception? $\quad 1$ Yes 0 No

42. Were you tested (and if necessary treated) for any sexually transmitted diseases? $\quad \begin{array}{lllll}1 & \text { Yes } & 0 & \text { No }\end{array}$

43. How would you rate your satisfaction with the provision of the physical examination?

1 Very Dissatisfied 2 Somewhat Dissatisfied 3 Somewhat Satisfied 4 Very Satisfied

If dissatisfied, explain why.

44. How would you rate your satisfaction with the provision of the testing service for sexually transmitted diseases?

1 Very Dissatisfied 2 Somewhat Dissatisfied 3 Somewhat Satisfied 4 Very Satisfied

If dissatisfied, explain why.

45. How would you rate your satisfaction with the delivery of information about the availability of emergency contraceptives?

1 Very Dissatisfied 2 Somewhat Dissatisfied 3 Somewhat Satisfied 4 Very Satisfied

If dissatisfied, explain why.

46. Please rate the importance to you of the following medical services:

a) Testing for and treating sexually transmitted diseases

1 Very Important 2 Somewhat Important 3 Not At All Important

b) Medical treatment for injuries

1 Very Important 2 Somewhat Important 3 Not At All Important 
c) Offering emergency contraception (morning-after pill, Plan B)

1 Very Important $\quad 2$ Somewhat Important 3 Not At All Important

d) Collection of evidence

1 Very Important 2 Somewhat Important 3 Not At All Important

47. Who paid for the medical services (such as examination, treatment for sexually transmitted diseases, or emergency contraception) you received?

1 Insurance 2 Out-Of Pocket 3 No Charge 4 Other

48. Are you aware that in the state of Maryland you are not to be charged a fee from the hospital for medical treatment related to sexual assault services if you report the assault to the police? 1 Yes 0 No

IF NO, SKIP TO QUESTION 49.

If you were aware of this policy, did this influence your decision to report the assault to the police?

$$
1 \text { Yes } \quad 0 \quad \text { No }
$$

49. Have you ever received a bill from the hospital for services related to a sexual assault even though you reported the assault to the police? 1 Yes 0 No

LAW ENFORCEMENT - I am going to ask some questions about interactions with the law enforcement system.

50. Did you tell the police about the sexual assault? 1 Yes 0 No

IF YES, SKIP TO QUESTION 52.

If not, why not?

51. Do you plan to tell the police (make a police report)? $\quad 1$ Yes $\quad 0 \quad$ No

IF YES, SKIP TO QUESTION 72 UNDER SEEKING SERVICES FROM A SEXUAL ASSAULT CRISIS CENTER ON PAGE 9.

If not, why not?

SKIP TO QUESTION 72 UNDER SEEKING SERVICES FROM A SEXUAL ASSAULT

\section{CRISIS CENTER ON PAGE 9}

52. How long after the sexual assault did you tell the police?

53. Do you think the police believed you? 1 Yes 0 No 
54. What made you think that the police did or did not believe you?

55. Have criminal charges been filed against the person who assaulted you? 1 Yes 0 No

IF YES, SKIP TO QUESTION 57

If not, why not?

56. Do you plan to initiate criminal charges against the person who assaulted you? $\quad \begin{array}{lllll}1 & \text { Yes } & 0 & \text { No }\end{array}$

IF YES, SKIP TO QUESTION 57

If not, why not?

\section{$\underline{\text { SKIP TO QUESTION } 58}$}

57. Was the person who assaulted you arrested? $\quad 1$ Yes $\quad 0$ No

58. How would you rate your satisfaction with how the police interviewed you regarding the assault?

1 Very Dissatisfied 2 Somewhat Dissatisfied 3 Somewhat Satisfied 4 Very Satisfied

If dissatisfied, explain why.

59. How would you rate your satisfaction with how the police handled/pursued your case?

1 Very Dissatisfied 2 Somewhat Dissatisfied 3 Somewhat Satisfied 4 Very Satisfied

If dissatisfied, explain why.

60. How would you rate your satisfaction with your overall interactions with the police?

1 Very Dissatisfied 2 Somewhat Dissatisfied 3 Somewhat Satisfied 4 Very Satisfied

If dissatisfied, explain why.

\section{PROSECUTION/COURT PROCESS}

61. Did you interact with the prosecutor's office? 1 Yes $\quad 0$ No

IF YES, SKIP TO QUESTION 62.

If not, why not?

SKIP TO QUESTION 72 UNDER SEEKING SERVICES FROM A SEXUAL ASSAULT CENTER ON PAGE 9. 
62. How often did you speak with the prosecutor?

63. Do you think the prosecutor believed you? 1 Yes $\begin{array}{llll}0 & \text { No }\end{array}$

64. What made you think that the prosecutor did or did not believe you?

65. Were you assigned a victim advocate in the prosecutor's office? 1 Yes $\begin{array}{llll}0 & \text { No }\end{array}$

66. Were you informed of the availability of victim assistance funds? 1 Yes $\quad 0$ No

67. Was your case prosecuted? 1 Yes 0 No

\section{IF YES, SKIP TO QUESTION 68}

If not, why not?

68. How would you rate your satisfaction with your interactions with the prosecutor's office?

1 Very Dissatisfied 2 Somewhat Dissatisfied 3 Somewhat Satisfied 4 Very Satisfied

If dissatisfied, explain why.

69. How would you rate your overall satisfaction with the court process?

1 Very Dissatisfied 2 Somewhat Dissatisfied 3 Somewhat Satisfied 4 Very Satisfied

If dissatisfied, explain why.

70. Was the perpetrator convicted?

1 Yes 0 No

IF NO, SKIP TO QUESTION 71.

Did the perpetrator serve jail time? $\quad 1$ Yes 0 No

71. Who paid for any legal assistance services you received?
1 Out-Of Pocket
2 No Charge
3 Other
4 Didn’t Use

SEEKING SEXUAL ASSAULT SERVICES FROM A SEXUAL ASSAULT CRISIS CENTER - I am going to ask you some questions about receiving services to help you deal with the sexual assault.

72. Did you receive services from a sexual assault crisis center? $\quad 1$ Yes 0 No

IF YES, SKIP TO QUESTION 73

If not, why not? 


\section{SKIP TO QUESTION 94 UNDER SEEKING OTHER COUNSELING SERVICES}

\section{SECTION ON PAGE 13}

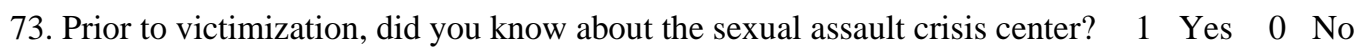

74. Did you have any problems finding a sexual assault crisis center? 1 Yes 0 No

IF NO, SKIP TO QUESTION 75.

What problems did you have?

75. How did you learn about the sexual assault crisis center where you went? (Circle all that apply.)

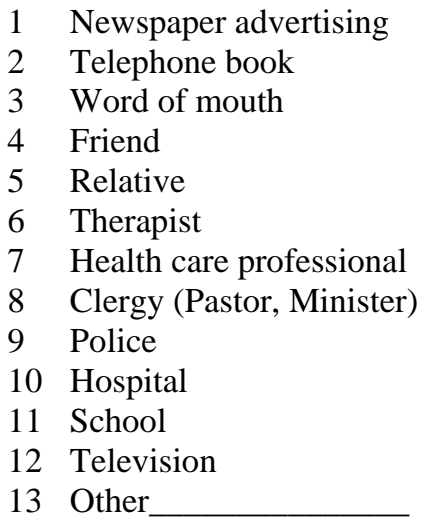

76. In what county was the sexual assault crisis center where you received services?

County:

77. How long after you were assaulted did you come to the sexual assault crisis center?

1 Within 24 hours of incident

Within 1 week

Within 1 month

Within 2-6 months

Within 6-12 months

6 More than 1 year

IF 1, SKIP TO QUESTION 78.

What prevented you from going for services sooner?

78. What prompted you to seek care at the sexual assault crisis center? (Circle all that apply.)

1 Family suggestion

Friend suggestion

Referral from police officer

4 Referral from hospital

5 Felt anxious or depressed (bad feelings that wouldn't go away)

6 Wanted to talk with someone who understood what you had been through 
7 Relationship problems

8 Nightmares/flashbacks

9 Trouble at work

10 General hard time functioning

11 Something similar happened to your child

12 Other, specify:

79. What was your first point of contact with the sexual assault crisis center?

1 Hotline

2 Victim advocate at hospital

3 Other

80. How would you rate the overall sexual assault services that you received from the sexual assault crisis center?
1 Very poor
2 Poor
3 Adequate
4 Good
5 Excellent

81. Did you receive individual counseling services at the sexual assault crisis center? 1 Yes $\quad 0$ No

IF NO, SKIP TO QUESTION 82.

How many individual counseling sessions did you attend per week?

How long did you receive individual counseling? service?

How would you rate your satisfaction with the provision of individual counseling

1 Very Dissatisfied 2 Somewhat Dissatisfied 3 Somewhat Satisfied

4 Very Satisfied

If dissatisfied, explain why.

82. Did you receive group counseling services at the sexual assault crisis center? 1 Yes $\quad 0$ No

IF NO, SKIP TO QUESTION 83.

How many group counseling sessions did you attend per week?

How long did you receive group counseling?

How would you rate your satisfaction with the provision of group counseling service?

1 Very Dissatisfied 2 Somewhat Dissatisfied 3 Somewhat Satisfied 4 Very Satisfied

If dissatisfied, explain why.

83. Did you call the sexual assault hotline at the sexual assault crisis center? $\quad \begin{array}{llll}1 & \text { Yes } & 0 & \text { No }\end{array}$

IF NO, SKIP TO QUESTION 84. service?

How would you rate your satisfaction with the provision of the sexual assault hotline 
1 Very Dissatisfied 2 Somewhat Dissatisfied 3 Somewhat Satisfied 4 Very Satisfied

If dissatisfied, explain why.

84. Did you receive legal services at the sexual assault crisis center? 1 Yes $\quad 0$ No

\section{IF NO, SKIP TO QUESTION 85.}

How would you rate your satisfaction the provision of legal services?

1 Very Dissatisfied 2 Somewhat Dissatisfied 3 Somewhat Satisfied 4 Very Satisfied

If dissatisfied, explain why.

85. Did you receive advocacy services, such as accompaniment for police interviews, hospital visits, and/or court appearances, from the sexual assault crisis center? 1 Yes 0 No

IF NO, SKIP TO QUESTION 86.

How would you rate your satisfaction with the provision of advocacy services?

1 Very Dissatisfied 2 Somewhat Dissatisfied 3 Somewhat Satisfied 4 Very Satisfied

If dissatisfied, explain why.

86. Were you referred to another agency for additional services? $\quad \begin{array}{llll}1 & \text { Yes } & 0 & \text { No }\end{array}$

IF NO, SKIP TO QUESTION 90.

87. What additional services were you referred for? (Circle all that apply.)

1 Legal assistance

Medical services

3 Mental health counseling

4 Social services

5 Substance abuse counseling

6 Domestic violence counseling

7 Other

88. How would you rate your satisfaction with the provision of the referral service?

1 Very Dissatisfied 2 Somewhat Dissatisfied 3 Somewhat Satisfied 4 Very Satisfied

If dissatisfied, explain why. 
89. Who paid for other referred services you received?
1 Insurance
2 Out-of pocket
3 No charge
4 Other

90. How important were the following to you?

1 Helping you cope with difficult feelings
1 Very Important
2 Somewhat Important
3 Not At All Important

2 Helping with legal matters
1 Very Important
2 Somewhat Important
3 Not At All Important

3 Helping you decide how to tell people you think need to know
1 Very Important
2 Somewhat Important
3 Not At All Important

4 Helping you create a support system
1 Very Important
2 Somewhat Important
3 Not At All Important

5 Confidentiality
1 Very Important
2 Somewhat Important
3 Not At All Important

91. Did you receive a statement of confidentiality from the sexual assault crisis center? 1 Yes 0 No

92. On a scale of 1 to 10 , with 1 being not sure at all and 10 being very sure, how confident are you that your discussions were kept confidential at the sexual assault crisis center?

Not sure at all

12

3

4

4

5

\section{6}

7

8

$9 \begin{array}{cc}\text { Very sure } \\ 9 & 10\end{array}$

93. Who paid for counseling services you received?
1 Insurance 2 Out-of pocket
3 No charge
4 Other

\section{SEEKING OTHER COUNSELING SERVICES}

94. Did you get counseling services from a place other than a sexual assault crisis center? 1 Yes 0 No

\section{IF NO, SKIP TO QUESTION 103 UNDER RECOMMENDATIONS FOR IMPROVEMENT SECTION ON PAGE 14}

95. Where did you receive counseling services for sexual assault other than a sexual assault crisis center? (Circle all that apply.)

1 Church/pastor 
2 Therapist/counselor

3 Hospital

4 Other (specify)

96. How long after you were assaulted did you receive counseling services?

1 Within 24 hours of incident

2 Within 1 week

3 Within 1 month

4 Within 2-6 months

5 Within 6-12 months

6 More than 1 year

IF ANSWER WAS 1, SKIP TO QUESTION 97.

What prevented you from going for services sooner?

97. What prompted you to seek counseling services? (Circle all that apply.)

1 Family suggestion

2 Friend suggestion

3 Police officer

4 Hospital referral

5 Felt anxious or depressed (bad feelings that wouldn't go away)

6 Wanted to talk with someone who understood what you had been through

7 Relationship problems

8 Nightmares/flashbacks

9 Employee assistance program

10 General hard time functioning

11 Something similar happened to your child

12 Other, specify:

98. Did you receive individual counseling services? $\quad 1$ Yes 0 No IF NO, SKIP TO QUESTION 99.

How many individual counseling sessions did you attend per week?

How long did you receive individual counseling? services?

How would you rate your satisfaction with the provision of individual counseling
1 Very Dissatisfied
2 Somewhat Dissatisfied
3 Somewhat Satisfied
4 Very Satisfied

If dissatisfied, explain why.

99. Did you receive group counseling services?

1 Yes 0 No

IF NO, SKIP TO QUESTION 100.

How many group counseling sessions did you attend per week?

How long did you receive group counseling? 


\section{How would you rate your satisfaction with the provision of group counseling services?}

\section{Very Dissatisfied 2 Somewhat Dissatisfied 3 Somewhat Satisfied 4 Very Satisfied}

If dissatisfied, explain why.

100. Who paid for counseling services you received?

1 Insurance 2 Out-of pocket 3 No charge 4 Other

101. Did you receive a statement of confidentiality from the person you received counseling services from? 1 Yes 0 No

102. On a scale of 1 to 10 , with 1 being not sure at all and 10 being very sure, how confident are you that your discussions were kept confidential?

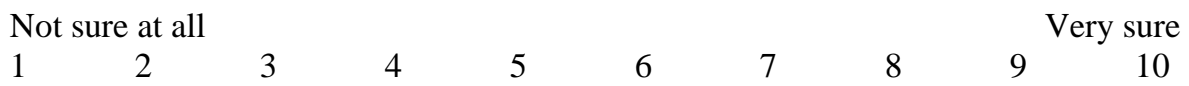

RECOMMENDATIONS FOR IMPROVEMENT - I am now going to ask you some questions about your overall experience in receiving services for sexual assault.

103. Looking back, what was the biggest problem or difficulty you had in your sexual assault treatment experience?

104. What service or experience was the most helpful to you?

105. What are the strategies you used in coping with the aftermath of the sexual assault?

106. Do you think your race/ethnicity was a factor in how people responded to you? 1 Yes 0 No

If yes, why or how?

107. Do you think race/ethnicity of the perpetrator was a factor in how people responded to you?

$$
1 \text { Yes } \quad 0 \text { No }
$$

If yes, why or how?

108. What would you recommend to your community as ways to improve how it responds to people who have been sexually assaulted? 
109. If you could make one recommendation to the state for improvement of the sexual assault treatment service in Maryland, what would it be?

110. Is there anything you would like to say?

That is all the questions I have. Thank you for taking the time to be interviewed for this study. 


\section{Addendum to the Interview Instrument}

Questions 28 through 30

Person told (number from question 27)

How did that person react when you told them?

Based on the person's reaction, did it appear that they believed you? 1 Yes 0 No

What made you think that they did or did not believe you?

Person told (number from question 27)

How did that person react when you told them?

Based on the person's reaction, did it appear that they believed you? 1 Yes 0 No

What made you think that they did or did not believe you?

Person told (number from question 27)

How did that person react when you told them?

Based on the person's reaction, did it appear that they believed you? 1 Yes 0 No

What made you think that they did or did not believe you? 
This document is a research report submitted to the U.S. Department of Justice. This report has not been published by the Department. Opinions or points of view expressed are those of the author(s) and do not necessarily reflect the official position or policies of the U.S. Department of Justice. 


\section{Appendix D: Items From the Interview Instrument Used to Explore Study Hypotheses}

\begin{tabular}{|c|c|c|}
\hline Hypothesis & Variable & Item \# \\
\hline $\begin{array}{l}\text { 1A: African American women will be more } \\
\text { likely to experience sexual assault by a } \\
\text { stranger than Caucasian women. }\end{array}$ & $\begin{array}{l}\text { Relationship of } \\
\text { perpetrator }\end{array}$ & 9 \\
\hline $\begin{array}{l}\text { 1B: African American women will be more } \\
\text { likely to experience a greater intensity of } \\
\text { assault (having a weapon used against them, } \\
\text { greater force) than Caucasian women. }\end{array}$ & $\begin{array}{l}\text { Ways attacked } \\
\text { Physical injuries } \\
\text { If weapon used }\end{array}$ & $\begin{array}{l}13 \\
14,15 \\
16\end{array}$ \\
\hline $\begin{array}{l}\text { 2A1: Fewer African American women will } \\
\text { indicate that they reported their sexual } \\
\text { assault to police than Caucasian women. }\end{array}$ & $\begin{array}{l}\text { Told police about assault } \\
\text { Filed charges } \\
\text { Plan to file charges }\end{array}$ & $\begin{array}{l}50 \mathrm{~A} \\
55 \\
51\end{array}$ \\
\hline $\begin{array}{l}\text { 2A2: African American women will indicate } \\
\text { a number of racial and cultural barriers in } \\
\text { reporting sexual assault to police. }\end{array}$ & $\begin{array}{l}\text { Race of perpetrator } \\
\text { Reason for not going to } \\
\text { police } \\
\text { Satisfaction with how } \\
\text { treated by police } \\
\text { Believed by police }\end{array}$ & $\begin{array}{l}10 \\
50 \mathrm{~B} \\
58,59,60 \\
53\end{array}$ \\
\hline $\begin{array}{l}\text { 2B1: Fewer African American women will } \\
\text { indicate that they sought medical and } \\
\text { psychological services following sexual } \\
\text { assault than Caucasian women. }\end{array}$ & $\begin{array}{l}\text { Received medical } \\
\text { treatment } \\
\text { Received services from } \\
\text { rape crisis center } \\
\text { Received other counseling }\end{array}$ & $\begin{array}{l}31 \\
72,80,81,82, \\
84,85 \\
94,95,98,99\end{array}$ \\
\hline $\begin{array}{l}\text { 2B2: African American women will report a } \\
\text { number of racial and cultural barriers in } \\
\text { seeking and receiving medical and } \\
\text { psychological services following sexual } \\
\text { assault. }\end{array}$ & $\begin{array}{l}\text { Reason for not seeking } \\
\text { medical services or } \\
\text { counseling } \\
\text { Satisfaction with services } \\
\\
\text { Informed of emergency } \\
\text { contraception } \\
\text { Tested for STDs } \\
\text { How long it took to come } \\
\text { to crisis center } \\
\text { What prevented them } \\
\text { from coming to crisis } \\
\text { center sooner } \\
\text { How long it took to go for } \\
\text { counseling }\end{array}$ & $\begin{array}{l}\begin{array}{l}32,72 * * \\
43,44,45,81, \\
82,83,84,85, \\
88,99,98\end{array} \\
40 \\
42 \\
77 \mathrm{~A} \\
77 \mathrm{~B} \\
96 \mathrm{~A}\end{array}$ \\
\hline $\begin{array}{l}\text { 2C1: African American women will report } \\
\text { receiving less medical and psychological care } \\
\text { and will report more problems receiving this } \\
\text { care than Caucasian women. }\end{array}$ & $\begin{array}{l}\text { Reasons for not reporting } \\
\text { rape, going for services, or } \\
\text { dissatisfaction }\end{array}$ & $\begin{array}{l}32,43,44,45 \\
50 \mathrm{~B}, 51 \mathrm{~B} \\
55,56,58 \\
59,60\end{array}$ \\
\hline
\end{tabular}




\begin{tabular}{|l|l|l|}
\hline \multicolumn{1}{|l|}{} & & $\begin{array}{l}68,69,72 \mathrm{~B}, \\
81 \mathrm{E}, 83 \mathrm{C}, \\
88,84,85, \\
98,99,\end{array}$ \\
& & \\
& & \\
& $\begin{array}{l}\text { Race/ethnicity a factor in } \\
\text { how treated } \\
\text { Perpetrator's race/ } \\
\text { ethnicity a factor in how } \\
\text { treated } \\
\text { Perpetrator arrested } \\
\text { Case prosecuted } \\
\text { Biggest difficulty in } \\
\text { treatment experience }\end{array}$ & 106 \\
\hline \begin{tabular}{|l|l|}
\hline \multicolumn{2}{|c|}{} \\
3: African American women will be more \\
likely to utilize resources such as family, \\
friends, and faith communities to deal with \\
the aftermath of sexual assault than \\
Caucasian women.
\end{tabular} & $\begin{array}{l}\text { People told about assault } \\
\text { Received counseling from } \\
\text { clergy } \\
\text { Coping strategies } \\
\text { Services or experience } \\
\text { most helpful }\end{array}$ & 107 \\
\hline
\end{tabular}

